\title{
Ichthyosaurs from the French Rhaetian indicate a severe turnover across the Triassic-Jurassic boundary
}

Valentin Fischer*, Henri Cappetta, Peggy Vincent, Géraldine Garcia, Stijn Goolaerts, Jeremy E. Martin, Daniel Roggero, Xavier Valentin

V. Fischer

Geology Department, Université de Liège, B18 Allée du 6 Août, 4000 Liège, Belgium. v.fischer@ulg.ac.be

V. Fischer, S. Goolaerts

Earth and History of Life O.D., Royal Belgian Institute of Natural Sciences, 29 Rue Vautier, 1000 Brussels, Belgium. stijn.goolaerts@naturalsciences.be

\section{H. Cappetta}

Equipe "Paléontologie", UMR 5554 "Institut des Sciences de l'Evolution", Université de Montpellier II - Sciences et Techniques du Languedoc, Cc 064, Place Eugène Bataillon, 34095Montpellier Cedex 5, France. henri.cappetta@univmontp2.fr

P. Vincent

Sorbonne Universités, CR2P - CNRS, MNHN, UPMC-Paris 6, Département Histoire de la Terre, Muséum National d'Histoire Naturelle, CP 38, 57 rue Cuvier, 75005, Paris, France. pvincent@mnhn.fr

G. Garcia, X. Valentin IPHEP, UMR7262 CNRS, Université de Poitiers,TSA 51106, 6 rue M. Brunet, 86073 Poitiers France. geraldine.garcia@univ-poitiers.fr; xavier.valentin@univ-poitiers.fr

S. Goolaerts

Department of Earth \& Environmental Sciences, K.U. Leuven, Celestijnenlaan 200E, 3001 Heverlee, Belgium.

\section{J. E. Martin}

UMR 5276 CNRS, Laboratoire de Géologie de Lyon, Terre, Planètes et Environement, ENS de Lyon et Université de Lyon, Ecole Normale Supérieure de Lyon, 69364 Lyon Cedex 07, France. jeremy.martin@ens-lyon.fr

D. Roggero

25 avenue de lattre de Tassigny 13127 Vitrolles, France.

X. Valentin

Association de recherche paléontologique du Var, Vieux Fox, 83670 Fox-Amphoux, France.

RH: French Rhaetian ichthyosaurs

*Corresponding author. 
Abstract Mesozoic marine reptiles went through a severe turnover near the end of the Triassic. Notably, an important extinction event affected ichthyosaurs, sweeping a large part of the group. This crisis is however obscured by an extremely poor fossil record and is regarded as protracted over the entire Norian-earliest Jurassic interval, for the lack of a more precise scenario. The iconic whale-sized shastasaurid ichthyosaurs are regarded as early victims of this turnover, disappearing by the middle Norian. Here we evaluate the pattern of this turnover among ichthyosaurs by analyzing the faunal record of two Rhaetian localities. One locality is Autun, eastern France; we re-discovered in this material the holotypes or partial 'type' series of Rachitrema pellati, Actiosaurus gaudryi, Ichthyosaurus rheticus, Ichthyosaurus carinatus, and Plesiosaurus bibractensis; a revised taxonomic scheme is proposed. The second assemblage comes from a new locality: Cuers, southeastern France. Both these assemblages provide several lines of evidence for the presence of shastasaurid-like ichthyosaurs in the Rhaetian of Europe. These occurrences suggest that both the demise of shastasaurids and the sudden radiation of neoichthyosaurians occurred within a short time window; this turnover appear more abrupt but also more complex than previously postulated and adds a new facet of the end-Triassic mass extinction.

Keywords Ichthyosauria; Shastasauridae; Rhaetian; Latest Triassic extinction; Turnover.

\section{Introduction}

Ichthyosauria is a diverse clade of marine reptiles that spanned most of the Mesozoic (e.g. McGowan and Motani 2003). Until recently, most authors interpreted the fossil record as showing that three major extinction events affected this group: one during the Late or latest Triassic (LT), one at the Jurassic-Cretaceous boundary (JCB), and their total extinction at the Cenomanian-Turonian boundary (CTB) (e.g. Bardet 1992; Bakker 1993; Bardet 1994). Whereas the JCB extinction is now regarded as a minor event for ichthyosaurs (Fischer et al. 2012; Fischer et al. 2013), the LT and CTB extinctions are considered as severe (Thorne et al. 2011; Fischer et al. 2014). A very large portion of ichthyosaur diversity and disparity vanished in the course of LT extinction; only the open ocean-adapted parvipelvians survived (McGowan 1997; Thorne et al. 2011), and then rapidly radiated at the TriassicJurassic boundary and during the Jurassic (Fischer et al. 2013). However, the last unambiguous record of non-parvipelvian ichthyosaurs is middle Norian (e.g. McGowan 1997; Nicholls and Manabe 2004) and no diagnostic remains are known from the entire late Norian-Rhaetian interval, worldwide. The recent discovery of a possible non-parvipelvian ichthyosaur in the earliest Jurassic of Wales (Martin et al. In Press) indicates that our understanding of the tempo and amplitude of these events remain largely unknown, as is their synchronicity with other biotic and abiotic events (Benson et al. 2012).

Only a handful of marine reptile occurrences have been reported in Rhaetian strata (see for example, the compilations of Bardet et al. 2014; Kelley et al. 2014). Besides the scarce material reported from southern France, Austria, and England (Corroy 1933; Zapfe 1976; Storrs 1994), Sauvage $(1876,1883,1903)$ described abundant reptilian material and several new taxa from the 'Pellat' and 'Dumortier' collections, originating from latest Triassic strata in the Autun area, eastern France. This collection is therefore of crucial importance to understand the diversity dynamics near the end of the Triassic. However, this material was dispersed and considered as lost (Gand et al. 2012). S.G. and V.F. re-discovered most of this material in the collections of the Katholieke Universiteit Leuven (K.U. Leuven), Belgium (Table 1).

In order to evaluate the timing and modalities of the latest Triassic ichthyosaur turnover, (1) we reassess the ichthyosaur material of Sauvage, clarify its taxonomy and retrace its research history (see Electronic Supplementary Material [ESM]); (2) we describe new ichthyosaur remains and assess the stratigraphy of another Rhaetian locality, Cuers, in southern France. Then, (3) we review and discuss the ichthyosaur extinctions and radiations of the Norian-Hettangian interval in light of the new 
data and (4) replace it into a brief synoptic view of the end-Triassic turnover among marine reptiles, frequently considered as one of the 'big five' Phanerozoic mass extinctions (Wignall and Bond 2008).

\section{Material and methods}

Institutional Abbreviations

MHNTV, Muséum d'Histoire naturelle de Toulon et du Var, Toulon, France. MHNA, Muséum d'Histoire naturelle d'Auxerre, Auxerre, France ; PLV, Palaeontology collections, Katholieke Universiteit Leuven (K.U. Leuven), Belgium; ROM, Royal Ontario Museum, Toronto, Ontario, Canada. UCMP, University of California Museum of Paleontology, Berkeley, U.S.A. UM-CUE, University of Montpellier2, Paleontological collections, Montpellier, France.

Geographic and geological setting

Cuers This site is located along the D43 road around 'Saint-Laurens', Var (83), France (Fig. 1). The section corresponds to a succession of Triassic bioclastic limestone beds containing numerous remains of chondrichthyans, teleosts, gastropods, crinoids, and bivalves, in association with ferruginous ooliths and quartz. The bioclastic limestone is interbedded with numerous argillaceous beds (Fig. 2), as in other contemporaneous localities in the region (Caron 1967). The ichthyosaur remains studied here originate from a shale bed (Fig. S1 in ESM). Another shale bed a few meters above concentrates a diversified assemblage of teleosts (Birgeria, Sargodon, Lepidotus) and selachians (see below) (Agassiz 1833-43; Quenstedt 1856-1858; Corroy 1933; Charles 1948). Our sampling of the SaintLaurens reveals an elasmobranch assemblage dominated by well-preserved hybodont remains, most of which being referable to Lissodus minimus (Agassiz, 1833-43). Other hybodonts (Hybodus sp., Polyacrodus sp., Pseudodalatias barnstonensis (Sykes, 1971), neoselachians (Rhomphaiodon nicolensis Duffin, 1993) and Pseudocetorhinus pickfordi Duffin, 1998 (order and family incertae sedis) complete this diverse assemblage (Cappetta 2012; Fig. S2 in ESM); a detailed account on the shark fauna from Cuers will be published in another venue. This assemblage closely resembles that of a nearby locality analyzed by Corroy (1933): Hybodus minor Agassiz, 1833-43, H. cloacinus Quenstedt, 1856-1858, Lissodus minimus and Nemacanthus monilifer (Agassiz, 1833-43) and that of Habay-la-vieille (Rhaetian of Belgium [Delsatte and Lepage 1991; Duffin and Delsatte 1993]), strongly suggesting a Rhaetian age for the Cuers locality.

Autun Most specimens originate from a bonebed in the "Grès à Avicula contorta" (Grès Blonds Formation) of the Autun area, Saône-et-Loire (71), Burgundy, France. The bivalve now known as Rhaetavicula contorta is indicative of the Rhaetian stage (e.g. Hautmann 2001). Two localities have yielded specimens analysed here: Antully and La Coudre; both are small villages in the vicinity of Autun (Fig. 1; Gand et al. 2012). Other specimens from the same area are preserved in a upper Rhaetian argillaceous limestone (Gand et al. 2012). All fossils from this area are thus unambiguously Rhaetian in age; however, more precise stratigraphic data for the bonebed is currently lacking.

Taxonomy assessment in bone-bed deposits

Sauvage (1883) recognized several taxa within the Autun material and referred several bones to them, creating 'type' series. In the following section, we re-describe these series but we assess the taxonomic affinities of each bone independently, as both the nature of their hosting formation (a sandstone bonebed) and our re-assessment strongly suggest that these series are composed of multiple individuals and taxa. Then, we summarize our taxonomic reassessments in the Systematic Paleontology section and in Table 1. 
Table 1. Amniotans from the Pellat Collection with their successive assignments and their current location.

\begin{tabular}{|c|c|c|c|}
\hline Sauvage 1883 & Sauvage 1903 & This work & $\begin{array}{l}\text { Place curated and } \\
\text { catalog number }\end{array}$ \\
\hline Rachitrema pellati & & $\begin{array}{l}\text { Nomen dubium, } \\
\text { composite }\end{array}$ & \\
\hline Neural arch (holotype) & I. rheticus neural arch & $\begin{array}{l}\text { Ichthyosauria indet., } \\
\text { Shastasaurid-like or } \\
\text { cymbospondylid-like } \\
\text { neural arch }\end{array}$ & PLV 1939 \\
\hline Ribs & - & $\begin{array}{l}\text { Amniota indet., ribs or } \\
\text { gastralia }\end{array}$ & PLV 1951, 1952 \\
\hline Scapula & $\begin{array}{l}\text { Toretocnemus } \\
\text { (Leptocheirus) scapula }\end{array}$ & $\begin{array}{l}\text { Aff. Shastasauridae } \\
\text { scapula }\end{array}$ & PLV 1942 \\
\hline Humerus & Indet. & $\begin{array}{l}\text { Non-parvipelvian } \\
\text { Ichthyosauria, ilium }\end{array}$ & PLV 1940 \\
\hline Left radius & $\begin{array}{l}\text { Toretocnemus or } \\
\text { Shastasaurus ilium }\end{array}$ & $\begin{array}{l}\text { Plesiosauria indet., } \\
\text { propodial }\end{array}$ & PLV 1938 \\
\hline Left pubis & Indet. & $\begin{array}{l}\text { Amniota indet., possible } \\
\text { ichthyosaur coracoid }\end{array}$ & PLV 1943 \\
\hline Mastoidien & - & $\begin{array}{l}\text { Amniota indet., probable } \\
\text { ichthyosaur surangular }\end{array}$ & PLV 1934 \\
\hline Skull element 1 & - & $\begin{array}{l}\text { Amniota indet., possible } \\
\text { mandible fragment }\end{array}$ & PLV 1941 \\
\hline Skull element 2 & - & $\begin{array}{l}\text { Amniota indet., possible } \\
\text { mandible fragment }\end{array}$ & $\begin{array}{l}\text { PLV } 1950 \text { (connects to } \\
\text { PLV 1959) }\end{array}$ \\
\hline Ichthyosaurus rheticus & & $\begin{array}{l}\text { Nomen dubium, } \\
\text { composite }\end{array}$ & \\
\hline Centrum 1 & - & - & $\begin{array}{l}\text { Possibly in Autun } \\
\text { seminary }\end{array}$ \\
\hline Centrum 2 & - & $\begin{array}{l}\text { Aff. Shastasauridae } \\
\text { thoracic centrum }\end{array}$ & PLV 1961 \\
\hline Centrum 3 & - & - & $?$ \\
\hline Centrum 4 & - & $\begin{array}{l}\text { Aff. Shastasauridae } \\
\text { thoracic centrum }\end{array}$ & PLV 1948 \\
\hline Centrum 5 & - & - & $?$ \\
\hline Femur 1 & - & Aff. Shastasauridae femur & PLV 1963 \\
\hline Femur 2 & - & - & In MHNA \\
\hline Scapula & - & $\begin{array}{l}\text { Aff. Shastasauridae } \\
\text { epipodial }\end{array}$ & PLV 1962 \\
\hline Ribs & - & Ichthyosauria indet. rib & PLV 1949? \\
\hline Ribs & - & $\begin{array}{l}\text { Amniota indet. (see PLV } \\
1950 \text { above) }\end{array}$ & PLV 1959 \\
\hline Ichthyosaurus carinatus & & $\begin{array}{l}\text { Nomen dubium, } \\
\text { composite }\end{array}$ & \\
\hline Centrum 1 & - & $\begin{array}{l}\text { Aff. Shastasauridae } \\
\text { thoracic centrum }\end{array}$ & PLV 1949 partim \\
\hline Centrum 2 & - & $\begin{array}{l}\text { Aff. Shastasauridae } \\
\text { thoracic centrum }\end{array}$ & PLV 10bis \\
\hline
\end{tabular}




\begin{tabular}{|c|c|c|c|}
\hline Centrum 3 & - & - & In MHNA \\
\hline Centrum 4 & - & - & In MHNA \\
\hline Mandible & - & $\begin{array}{l}\text { Aff. Shastasauridae } \\
\text { rostrum }\end{array}$ & $\begin{array}{l}\text { ? - PLV } 1964 \text { partim are } \\
\text { compatible remains }\end{array}$ \\
\hline Ribs & - & Ichthyosauria indet. rib & $\begin{array}{l}\text { PLV 1957, but not entire } \\
\text { series }\end{array}$ \\
\hline \multicolumn{2}{|c|}{ Plesiosaurus bibractensis } & \multicolumn{2}{|l|}{ Species inquirenda } \\
\hline $\begin{array}{l}\text { Cervical vertebra } \\
\text { (holotype) }\end{array}$ & - & $\begin{array}{l}\text { Pectoral or sacral } \\
\text { plesiosaur vertebra }\end{array}$ & PLV 1936 \\
\hline Dorsal vertebra 1 & - & - & Possibly in MHNA \\
\hline Dorsal vertebra 2 & - & caudal plesiosaur vertebra & PLV 1953 partim \\
\hline Dorsal vertebra 3 & - & dorsal plesiosaur vertebra & PLV 1949? \\
\hline Dorsal vertebra 4 & - & $\begin{array}{l}\text { Pectoral or sacral } \\
\text { plesiosaur vertebra }\end{array}$ & PLV 1953 partim \\
\hline Caudal vertebra & - & dorsal plesiosaur vertebra & PLV 1948 \\
\hline Ribs & - & - & Possibly in MHNA \\
\hline Femur & - & plesiosaur propodial & PLV 1954 \\
\hline \multicolumn{2}{|l|}{ Plesiosaurus costatus } & \multicolumn{2}{|l|}{ Species inquirenda } \\
\hline Cervical vertebra 1 & - & $\begin{array}{l}\text { cervical plesiosaur } \\
\text { centrum }\end{array}$ & PLV 1935 \\
\hline Cervical vertebra 2 & - & $\begin{array}{l}\text { cervical plesiosaur } \\
\text { centrum }\end{array}$ & PLV 1955 \\
\hline Cervical vertebra 3 & - & & Possibly in MHNA \\
\hline \multicolumn{2}{|l|}{ Actiosaurus gaudryi } & \multicolumn{2}{|l|}{ Species inquirenda } \\
\hline Femur 1 (holotype) & - & $\begin{array}{l}\text { Possible choristodere } \\
\text { propodial }\end{array}$ & PLV 1937 \\
\hline Femur 2 & - & - & $?$ \\
\hline Humerus & - & $\begin{array}{l}\text { Possible choristodere } \\
\text { propodial }\end{array}$ & $\begin{array}{l}\text { PLV } 1944 \text { (broken } \\
\text { original + cast) }\end{array}$ \\
\hline Vertebra & - & - & $?$ \\
\hline \multicolumn{4}{|l|}{ Additional material } \\
\hline- & - & $\begin{array}{l}\text { Numerous plesiosaur and } \\
\text { ichthyosaur centra }\end{array}$ & PLV 1945 \\
\hline
\end{tabular}



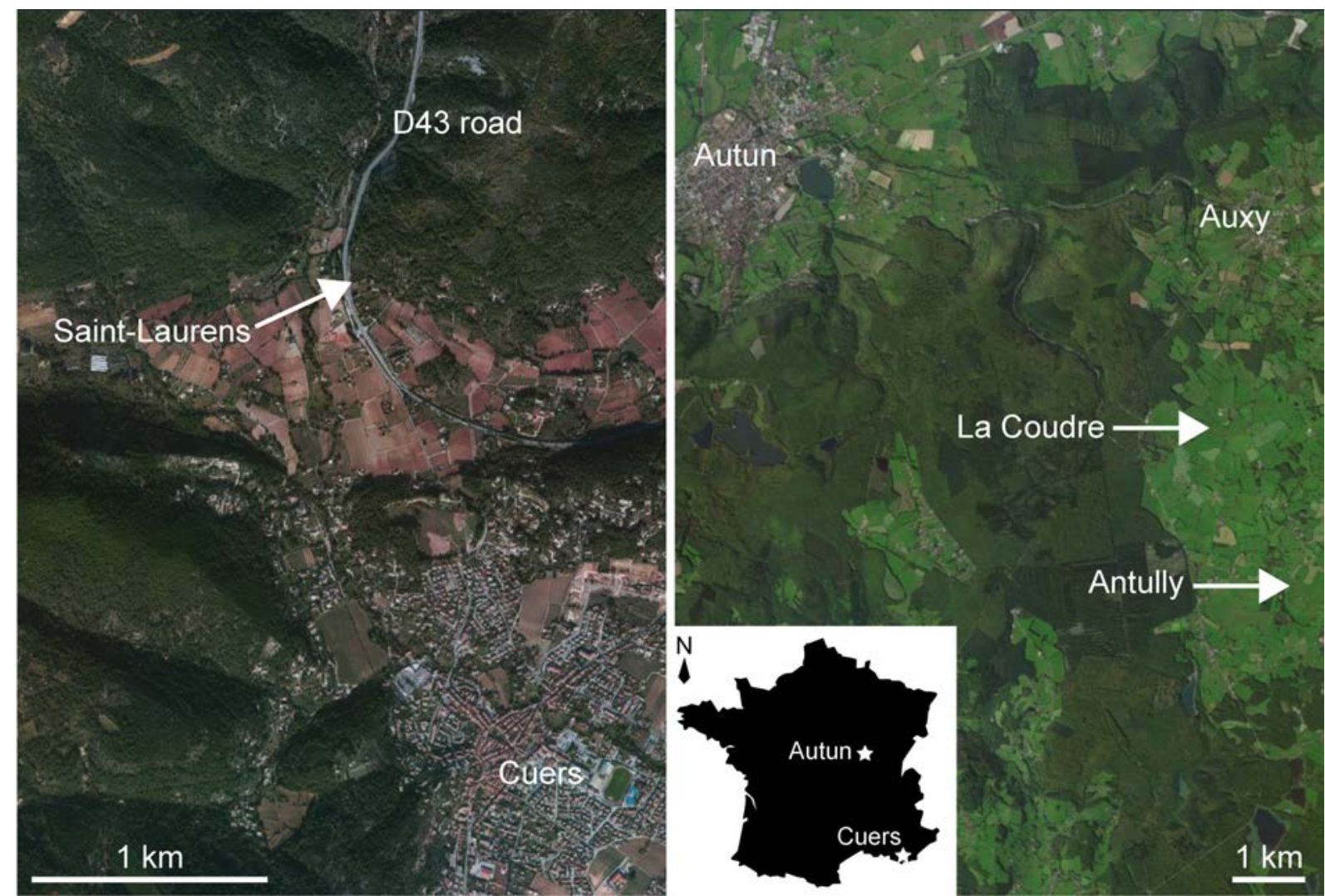

Fig. 1 Location of the two Rhaetian fossil sites analysed in this paper. Left: Saint-Laurens, near Cuers, Var, France. Right: La Coudre and Antully near Autun, Burgundy, France. Inset: France map with with Autun and Cuers.

\section{Comparative descriptions and affinities}

Cuers ichthyosaur

The ichthyosaur material from Cuers was discovered in close vicinity in a single bed and likely represents the remains of a single animal. This specimen was found during two distinct excavations by D.R. and X.V. and received two collection numbers, MHNTV PAL-1-10/2012 (premaxilla, centrum, partial ribs and indeterminate fragments) and MHNTV PAL-2/2010 (mandible, centrum, partial ribs and indeterminate fragments).

Premaxilla (MHNTV PAL-1-10/2012) A small rostrum fragment with a flat lateroventral facet (presumably for articulation with the maxilla), is interpreted as the premaxilla. A shallow fossa praemaxillaris is present. The dental groove is reduced and appears continuous, indicating an aulacodont or sub-thecodont tooth implantation (Motani 1997). The labial wall is much higher and thicker than the lingual wall and possesses a flat maxillary facet.

Mandible (MHNTV PAL-2/2010) This specimen is a mandible fragment measuring $1270 \mathrm{~mm}$ (Fig 2). The anterior part of the ramus is extremely slender (the long axis of its cross-section is only $79 \mathrm{~mm}$ long) and slightly arched, being markedly similar to that of Shonisaurus sikanniensis (see Figs 3, 4 in Nicholls and Manabe 2004) and the Ichthyosaurus carinatus mandible figured by Sauvage (1883: Pl. 8; see below). The fossa dentalis is discontinuous; it forms a straight succession of deep, anterolaterally-oriented foramina distant of $50 \mathrm{~mm}$. They fuse to form a continuous groove over about $100 \mathrm{~mm}$ the middle part of the bone.

A narrow, continuous dental groove is present; as in Ichthyosaurus carinatus (see below) but unlike other ichthyosaurs, the dental groove lies on the medial surface of the rostrum. As in the premaxilla, the labial wall is thick, whereas its lingual wall appears markedly reduced. Preservation 
and preparation damage have further reduced it to $5 \mathrm{~mm}$ thin lamella. As preserved, the dental groove is only $10 \mathrm{~mm}$ deep, which appears extremely small compared to the size of the mandible.

Shastasaurids are the only ichthyosaurs known to have substantially reduced their dental grooves; they are completely absent in Guanlingsaurus liangae and Shonisaurus sikanniensis (Nicholls and Manabe 2004; Sander et al. 2011). The floor of the dental groove of the Cuers ichthyosaur is smooth, continuous and there is no evidence of alveoli. This indicates an aulacodont mode of tooth implantation (Motani 1997).

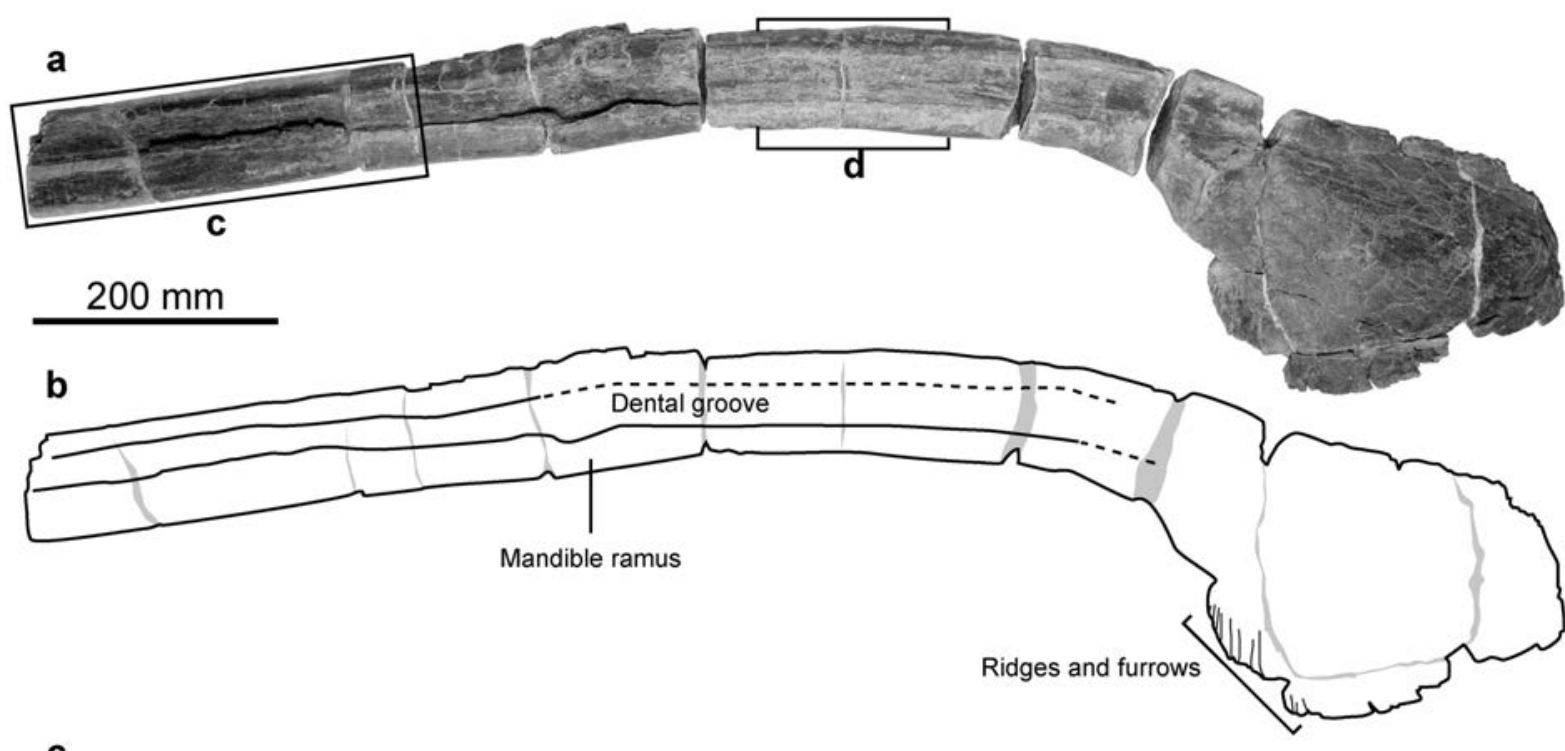

C

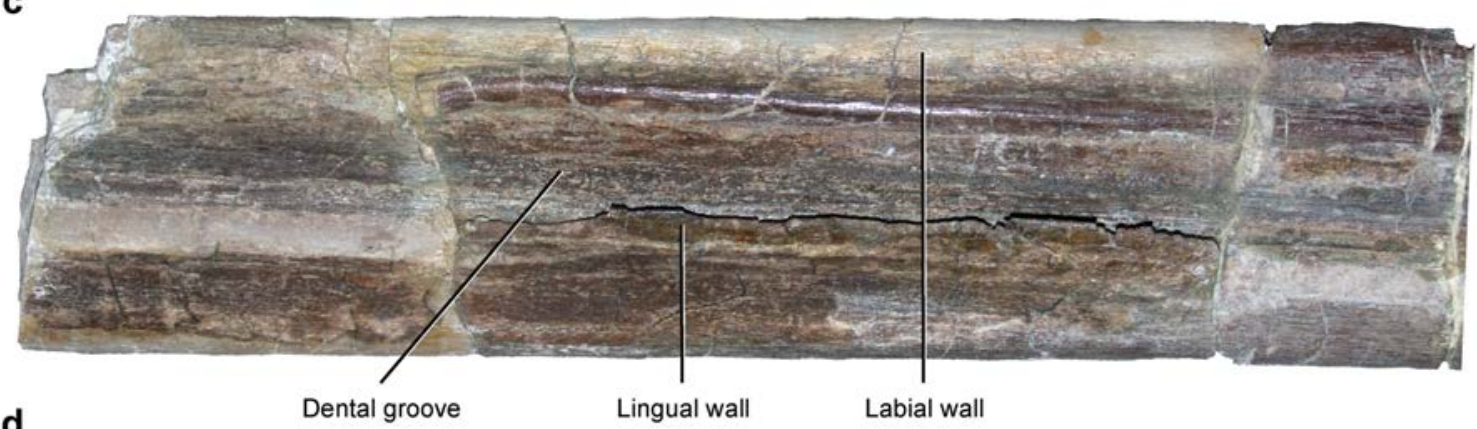

d

Dental groove

Lingual wall

Labial wall

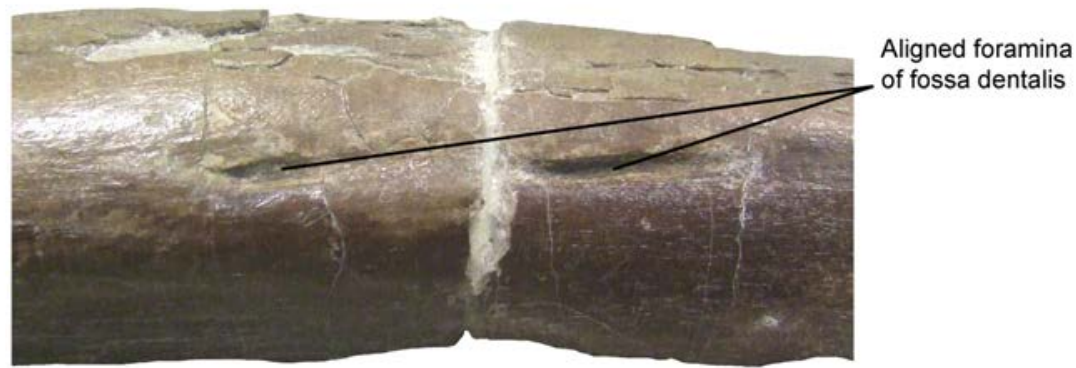

$50 \mathrm{~mm}$

Fig. 2 Mandibular remains from the Cuers ichthyosaur (MHNTV PAL-2/2010). a, photograph of the ?right mandible in lingual view; b, interpretative drawing; shaded zones in the interpretation represent cracks and missing bone. The posterior part of the mandible has been flattened along the bedding plane. c, close-up of the dental groove. $\mathbf{d}$, close-up of fossa dentalis.

No bone sutures are visible in MHNTV PAL-2/2010, suggesting that many bones of the mandible are fused or that the fossil recrystallized during diagenesis. The shape of the posterior part of the mandible is also unusual: the jaw ramus narrows laterally and expands dorsoventrally, forming a biconcave spatula. Deep striations ornate the anterodorsal edge of this region. Whereas the posterior 
part of the bone is unlike that of any ichthyosaur we are aware of, this bone is unmistakably ichthyosaurian in having an aulacodont tooth implantation and a lateral fossa dentalis. Because the anterior and the posterior ends of the mandible are missing, the total length of the mandible cannot be adequately estimated, but could have reached $2 \mathrm{~m}$ or more, since the ramus is still $80 \mathrm{~mm}$ high at the anterior-most section and the entire symphysis is missing.

Axial skeleton Two centra and rib fragments are preserved (Fig. S3 in ESM). The centrum of MHNTV PAL-2/2010 is $119 \mathrm{~mm}$ wide and its height/length ratio is high, reaching 4.76. The centrum of MHNTV PAL-1-10/2012 is similar, being $115 \mathrm{~mm}$ wide and has a height/length ratio of 5.47. Given the three-dimension preservation mode of the other remains, it is unlikely that this ratio results from excessive compaction, although it certainly influenced the value. The lateral surface of both centra is weathered so that no apophysis can be recognized accurately. The floor of the neural canal is preserved and is hourglass-shaped in dorsal view, as in the Autun material (see below) and Shonisaurus popularis (see Camp 1980) and unlike the straight, rectangular shape found in neoichthyosaurians (e.g. Godefroit 1993; McGowan and Motani 2003; Kolb and Sander 2009). The floor of the neural canal is pierced by numerous small foramina, as in the material from Autun). The ribs are markedly compressed anteroposteriorly. Median grooves are present on both their anterior and posterior surfaces, giving the ribs an 8-shaped cross-section. The depth of these grooves decreases distally.

Affinities Besides its large to gigantic size, the Cuers ichthyosaur displays two important characters: an aulacodont dentition and flattened centra. Increase of body size (skull length $\geq 40 \mathrm{~cm}$ in adults) is regarded as a synapomorphy for Longipinnati without Torectonemidae (Maisch and Matzke 2000:character 33). Amongst remaining Longipinnati, aulacodonty characterizes Neoichthyosauria, but can also be observed in the shastasaurid Shastasaurus pacificus (see Motani 1997; Table S1). Neoichthyosaurians do not have extremely flattened centra (e.g. Buchholtz 2001); such centrum morphology has not been described in Shastasaurus itself either, but definitely in other shastasaurids: the cervical centra of Himalayasaurus and the thoracic centra of some Shonisaurus species are characterized by a height/length ratio $\geq 3$ (Motani 1999; Maisch and Matzke 2000; Dalla Vecchia and Avanzini 2002; McGowan and Motani 2003; Nicholls and Manabe 2004). Finally, the extremely long and slender mandibles with nearly absent dental groove do not correspond to any parvipelvian taxa known so far; large neoichthyosaurians are present in the Hettangian-Sinemurian of western Europe, but either have robust mandible and dentition (Temnodontosaurus; e.g. Godefroit 1993) or a slender and diminutive mandible (Leptonectidae; e.g. McGowan 2003). The Cuers remains closely match the mandible morphology of shastasaurids, especially that of Shonisaurus sikanniensis, in forming a long, arched rod, that implies a reduced symphysis (Nicholls and Manabe 2004), unlike in leptonectid parvipelvians (e.g. McGowan 2003). The detailed morphology of shastasaurid mandible is however incompletely understood except in Shonisaurus popularis (see Camp 1980); as far as we know, the peculiar morphology of the posterior part of the Cuers mandible has not been documented in any ichthyosaurs.

The available data indicate that the Cuers ichthyosaur should be related to shastasaurid-like ichthyosaurs (as the monophyly of Shastasauridae is still debated: e.g. Maisch 2010; Ji et al. 2013). This specimen possesses a unique combination of characters: Shonisaurus- or Himalayasaurus-like centra and skull size but Shastasaurus-like aulacodont tooth implantation. The diversity of Late Triassic shastasaurids in terms of tooth implantation and tooth shape is surprisingly high, with the presence of edentulous, small-toothed aulacodont, subthecodont, and thecodont forms (Table S1 for details and references). In this context of high intragroup diversity and questioned monophyly of Shastasauridae, we assign this specimen to aff. Shastasauridae. 
Rachitrema pellati type series

Neural arch (PLV 1939) The holotype of $R$. pellati is a large complete neural arch that is $242 \mathrm{~mm}$ high (Fig 3). This taxon was previously assigned by Sauvage (1883) to Dinosauria; Huene (1902) and Sauvage (1903) then recognized its ichthyosaurian affinities. The pedicle has a semi-oval cross-section and is greatly thickened, strongly reducing the width of the neural canal to a narrow cleft. Unlike in neoichthyosaurians, the postzygapophyses are paired (Maisch and Matzke 2000). The neural spine thickens dorsally, a feature encountered in Cymbospondylus (see Maisch and Matzke 2000) and several shastasaurid taxa for which the neural spine is known ('Shastasaurus altispinus' [= S. pacificus according to McGowan and Motani 2003], Callawayia neoscapularis and Shonisaurus sikanniensis; Merriam 1908; Nicholls and Manabe 2001, 2004). More primitive and more derived ichthyosaurs, including Mixosaurus and the early neoichthyosaurian Temnodontosaurus platyodon, lack this feature (Merriam 1908; Godefroit 1993; Maisch and Matzke 2000); the neural spine of the early parvipelvians Hudsonelpidia and Macgowania is however unknown. The neural spine of $R$. pellati is straight and not offset posteriorly, as in Callawayia neoscapularis, Hudsonelpidia brevirostris, and Californosaurus perrini (Merriam 1908; McGowan 1995; Nicholls and Manabe 2001) and unlike in Shastasaurus pacificus (see Merriam 1908). Unusually, the neural spine is pierced by a large oval foramen situated above the zygapophyses.

Scapula (PLV 1942) The scapular blade is wide, unlike in Callawayia neoscapularis and parvipelvians, which possess a slender scapular blade (McGowan 1994, 1996b; Maisch and Matzke 2000) (Fig. 3). The scapula markedly differs from that of Cymbospondylus in seemingly lacking a prominent, isolated acromial process (Merriam 1908; Sander 1989), although the medial part of the scapula is not complete. The scapula closely resemble to that of Shonisaurus popularis in its general shape (see McGowan and Motani 1999; Maisch and Matzke 2000) and in lacking an anterior flange. Among non-parvipelvian ichthyosaurs, only Shonisaurus lacks this anterior flange (e.g. Maisch and Matzke 2000). PLV 1942 also lacks a medial notch, unlike in Shastasaurus (see Merriam 1902, 1908; Ji et al. 2013).

Ilium (PLV 1940) This specimen was previously regarded by Sauvage (1883) as a dinosaur humerus; he latter regarded it as a indeterminate ichthyosaur bone (Sauvage 1903); we regard it as an ichthyosaur ilium. The acetabular surface is round in cross-section and slightly dome-shaped (Fig 3 ). The ilium then becomes transversely flattened, and appears similar to the condition seen in Cymbospondylus (see Merriam 1908). The shape of the ilium indicates non-neoichthyosaurian affinities: the ilium possesses an anterior process, as many Middle-Late Triassic taxa such as Cymbospondylus petrinus, Californosaurus, and Hudsonelpidia (Merriam 1908; McGowan 1995; McGowan and Motani 2003). The neoichthyosaurian Suevoleviathan is the only post-Triassic ichthyosaur exhibiting this feature (Maisch 1998). Furthermore, the flattened shape of the iliac blade and the large size of the ilium (the preserved part, lacking a great part of the iliac blade is $126 \mathrm{~mm}$ high) indicate it does not belong to parvipelvian ichthyosaurs, which are characterized by a reduction of the pelvic girdle size and a styloidal iliac blade (Motani 1999). 


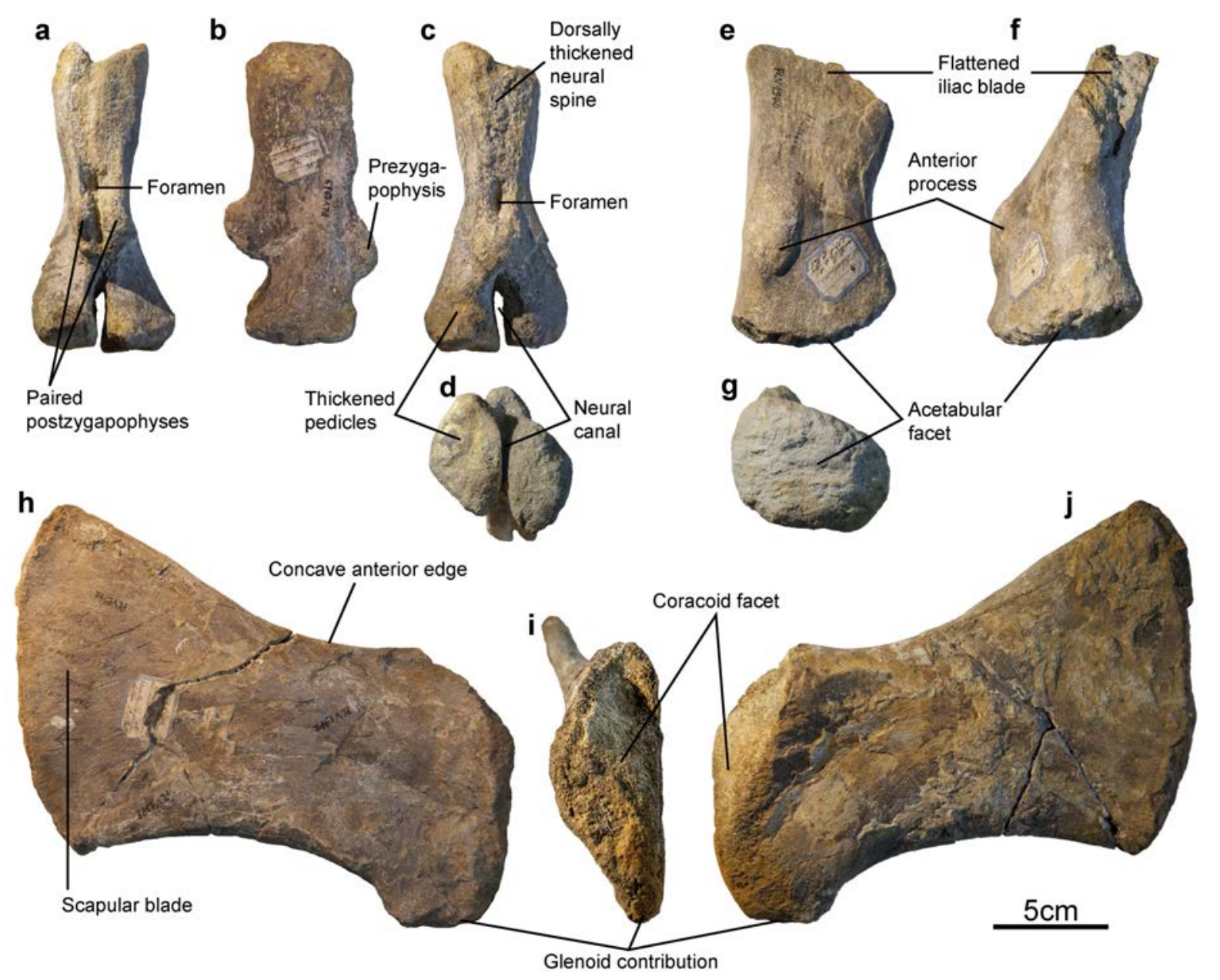

Fig. 3 Unambiguous ichthyosaur remains from the Rachitrema pellati type series. a-d, PLV 1939, a shastasaurid-like or cymbospondylid-like neural arch in a, posterior; b, lateral; c, anterior; d, ventral views. Note the thick pedicles and the central foramen. e-g, PLV 1940, a non-parvipelvian ichthyosaur ilium in e, anterior; $\mathbf{f}$, lateral; g, ventral views. Note the anterior process and the robust acetabular portion. h-j, PLV 1942, a Shonisaurus-like right scapula in $\mathbf{h}$, anterior, $\mathbf{i}$, medial; $\mathbf{j}$, posterior views. Note the elongated shape and distal fan.

Affinities We agree with Huene (1902), Sauvage (1903) and Bardet \& Cuny (1993) on the ichthyosaurian affinities of Rachitrema pellati. However, each fossil should be evaluated individually and some bones of the type series are not ichthyosaurian. The holotype specimen, a neural arch, was referred to as I. rheticus by Sauvage (1903). It is not compatible with neoichthyosaurians and bears numerous similarities with shastasaurid and cymbospondylid ichthyosaurs. It is unique in possessing a foramen dorsally to the zygapophyses. Another element of the type series of $R$. pellati, the scapula (PLV 1942), closely resembles that of shastasaurids, particularly Shonisaurus popularis. The ilium (PLV 1940) cannot be determined more precisely than Ichthyosauria indet., but its morphology is distinct from that of parvipelvian ichthyosaurs. The ribs (PLV 1951, PLV 1952) are of moderate to very large size (404 + $415 \mathrm{~mm}$ long for PLV 1951 and $305 \mathrm{~mm}$ long for PLV 1952), may indicate ichthyosaur affinities, but this attribution should be taken with caution; accordingly, we regard these remains as Amniota indet. here. Finally, some bones of the type series of $R$. pellati belong to other groups, notably a plesiosaur propodial (PLV 1938) and other elements (PLV 1934, PLV 1941, PLV 1943, PLV 1950_59) of unclear affinities (Table 1; Fig. S4 in ESM). 
Ichthyosaurus rheticus series

Ichthyosaurus rheticus and Ichthyosaurus carinatus were named and diagnosed by Sauvage (1876) on the basis of centra from the Pellat Collection, but this paper did not describe any specific remains, so that no holotype material can be selected. Sauvage (1883) latter described a series of remains that he assigned to I. rheticus and another that he assigned to I. carinatus; we assess these series below. Most specimens are these series are housed at the K.U. Leuven, but some others are located at the MHNA (Gand et al. 2012).

Centra (PLV 1948 partim, PLV 1961) Sauvage (1883) provided a number of measurements and descriptions of the centra he regarded as belonging to I. rheticus. Only two of them match these measurements and are labeled as such (PLV 1948 partim, PLV 1961). Other centra from Antully and La Coudre are present in the Pellat Collection at the K.U. Leuven (PLV 1932, PLV 1948 partim, PLV 1949 partim). All these centra have a prominent, extremely dorsoventrally elongated diapophysis, as in the thoracic centra of shastasaurids (Sander 1997; Lucas 2002) (Fig. 4). In PLV 1948 partim, the diapophysis merges with the anterior margin of the centrum ventrally. When present (in PLV 1948 partim), the parapophysis is a small but prominent bulge that merges with the anterior margin of the centrum. As in the centra of the Cuers ichthyosaur, the floor of the foramen magnum if these centra is hourglass-shaped in dorsal view and is pierced by numerous foramina in PLV 1932 and PLV 1949 partim.

Epipodial (PLV 1962) We interpret the specimen PLV 1962, regarded as a femur by Sauvage (1883), as an ichthyosaur epipodial of exceptionally large size, resembling that reported in Martin et al. (In Press). Both the proximal and distal surfaces are thicker than the shaft and are covered by pitted, unfinished bone. These surfaces are not parallel; the distal surface is offset by an angle of approximately $20^{\circ}$ (Fig. 4). The proximal surface is the longest and the thickest; this facet is straight and eye-shaped in proximal view. The distal surface is poorly preserved but its edge appears rounded in dorsal view. The shaft is proximodistally short and markedly flattened dorsoventrally, unlike in basal ichthyosaurs, where the shaft is more columnar, as in mixosaurids and Cymbospondylus (e.g. Merriam 1908; McGowan and Motani 2003). Both the anterior and posterior surfaces of the shaft are gently concave, indicating the presence of a large and oval spatium interosseum unlike in Toretocnemus and parvipelvians (e.g. Merriam 1908; McGowan 1995; Maisch 1998; McGowan and Motani 2003). There is no peripheral flange. This element resembles the radius of Pessopteryx, Besanosaurus and Shonisaurus popularis (Dal Sasso and Pinna 1996; McGowan and Motani 1999; Maisch 2002) but more closely resembles the tibia of Californosaurus (Merriam 1908) and shastasaurids, notably those of Guanlingsaurus liangae and Guizhouichthyosaurus tangae (Shang and Li 2009; Sander et al. 2011; Ji et al. 2013). Given the much older occurrence of Pessopteryx (Lower Triassic of Svalbard: Maisch 2010), PLV 1962 is here considered as an epipodial probably belonging to a shastasaurid or a closely related form (both Besanosaurus and Californosaurus are usually recovered as closely related or within shastasaurids: Maisch and Matzke 2000; Fröbisch et al. 2013; Ji et al. 2013).

Femur (PLV 1963) Although flattened dorsoventrally, the femur closely resembles that of shastasaurids, especially to those of Guanlingsaurus liangae and Shastasaurus osmonti Merriam 1908 (=Shastasaurus pacificus according to McGowan 1994) (Merriam 1908; Sander et al. 2011; Ji et al. 2013). It is short, unlike in Cymbospondylus (see Merriam 1908). The capitulum region is deeply concave, suggesting an immature age (Johnson 1977) (Fig. 4). A wide and low longitudinal trochanter is present on both the dorsal and ventral surfaces. According to Maxwell et al. (2012) the trochanter lying close to the anterior edge of the femur is the dorsal process. Thus, PLV 1963 is regarded as a right femur. It differs from that of Cymbospondylus, Toretocnemus zitteli and Californosaurus perrini in having a protruding anterodistal process (Merriam 1908). As in Shastasaurus pacificus, Shonisaurus popularis, Phantomosaurus, Besanosaurus, Mikadocephalus and Californosaurus but 
unlike in Toretocnemus zitteli, and basal neoichthyosaurians, the fibular facet is small and oriented posterolaterally (Merriam 1908; Camp 1980; Maisch and Matzke 2000; McGowan and Motani 2003).

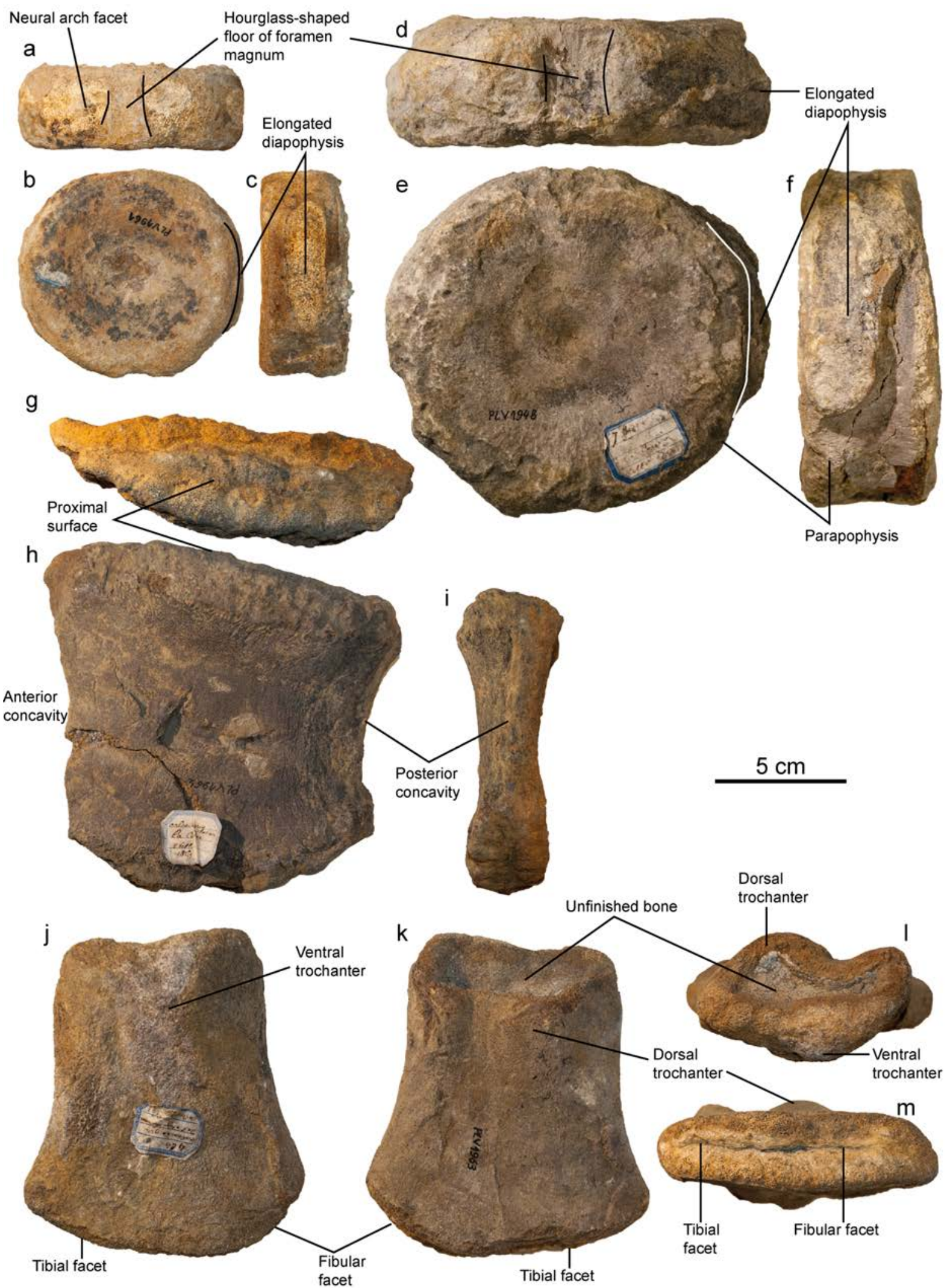

Fig. 4 Shastasaurid-like remains from the Ichthyosaurus rheticus series. a-c, PLV 1961, a centrum in a, dorsal; b, anterior; c, right lateral views. Note the elongated diapophysis. d-f, PLV 1948, a centrum in d, dorsal; e, anterior; f, right lateral views. Note the elongated diapophysis. g-i, PLV 1962, an epipodial in g, proximal, h, 
dorsal; i, posterior views. Note the anterior and posterior concavities. j-m, PLV 1963, a right femur in $\mathbf{j}$, ventral, $\mathbf{k}$, dorsal; l, proximal; $\mathbf{m}$, distal views.

Affinities As for Rachitrema pellati, the type series cannot be considered as belonging to a unique individual. Based on the drawing of Sauvage $(1883,1903)$, Bardet \& Cuny (1993) and Gand et al. (2012) regarded this species as a nomen dubium, and proposed shastasaurid affinities for this material. Our first-hand examination of the material indicates all remains attributed to I. rheticus are compatible with shastasaurids or closely related Triassic taxa, even when considered individually.

\section{Ichthyosaurus carinatus series}

Mandible (PLV 1964) Sauvage (1883: P1. 8) assigned a gigantic mandibular fragment to I. carinatus. This fragment, as well as centra and a femur are not in K.U. Leuven but the latter two are housed in the MHNA (Gand et al. 2012). Other mandibular remains (PLV 1964 partim) of similar size and morphology are part of the re-discovered material and may constitute the missing parts of the original fragment; we describe these remains below. PLV 1964 consists of a dentary fragment and a partial splenial. The dentary (Fig. S5 in ESM) is similar to that of the Cuers ichthyosaur and the specimen figured by Sauvage (1883: P1. 8) in having a continuous dental groove that lies on the medial face of the dentary; the medial wall of the dental groove is reduced to a thin lamella, as in the Cuers ichthyosaur and the specimen figured by Sauvage. The dental groove in PLV 1954 appears however much deeper than that of the Cuers ichthyosaur. A shallow but continuous fossa dentalis is present. As in the Cuers material, there is no evidence for the presence of a symphysis, hinting at an unusual mandible morphology for an ichthyosaur; more complete remains are however needed to unambiguously assess the mandible shape of the shastasaurid-like ichthyosaurs of the French Rhaetian. Yet, an extremely shortened mandibular symphysis has been described the shastasaurid Guanlingsaurus liangae (see Sander et al. 2011). The partial splenial is $335 \mathrm{~mm}$-long and is J-shaped, with a thickened ventral portion.

Centra (PLV 1949 partim, PLV 10bis) Two centra from Pellat Collection in K.U. Leuven match the measurements and descriptions of Sauvage (1883); PLV 1949 partim and PLV 10bis. The morphology of the centra, including the peculiar floor of foramen magnum is similar to that of the Cuers ichthyosaur and the remains attributed to I. rheticus.

Rib (PLV 1957) A partial rib from the Pellat Collection in the K.U. Leuven possesses two grooves giving the rib a number 8-shaped cross-section, as in the Cuers material.

Affinities Bardet \& Cuny (1993) regarded Ichthyosaurus carinatus as nomen dubium with possible shastasaurid affinities, but each remain should be analyzed individually. Our analysis indicates these remains closely resemble the material from Cuers and Autun are therefore regarded as belonging to shastasaurid-like ichthyosaurs.

\section{Systematic palaeontology}

Amniota Heckel 1866

Ichthyosauria Blainville 1835

Merriamosauria Motani 1999

Shastasauridae Merriam 1902

Aff. Shastasauridae

Referred specimens. MHNTV PAL-2/2010 and MHNTV PAL-1_10/2012 (incomplete skeleton comprising partial rostrum, centra, and rib fragments from the Rhaetian of Cuers); PLV 10bis (centrum); PLV 1942 (scapula); PLV 1948 (centrum); PLV 1949 partim (centrum); PLV 1961 (centrum); PLV 1962 (epipodial); PLV 1963 (femur); PLV 1964 partim (rostrum).All PLV material are from the Rhaetian of Autun area. 
Ichthyosauria indet.

Referred specimens. PLV 1939 (neural arch, holotype of R. pellati); PLV 1940 (ilium); PLV 1949

partim (rib); PLV 1957 (rib). All remains are from the Rhaetian of Autun area.

Plesiosauria Blainville 1835

Plesiosauria indet.

Referred specimens. PLV 1938 (propodial from the Rhaetian of the Autun area).

Amniota indet.

Referred specimens. PLV 1934 (possible surangular); PLV 1941 (possible mandible fragment); PLV 1943 (possible coracoid); PLV 1950 (possible mandible fragment); PLV 1951 (rib or gastralia); PLV 1952 (rib or gastralia); PLV 1959 (possible mandible fragment). All remains are from the Rhaetian of Autun area.

\section{Species inquirenda}

Plesiosaurus bibractensis: PLV 1936 (vertebra); PLV 1948 (vertebra); PLV 1949 partim (vertebra); PLV 1953 (two vertebra); PLV 1954 (propodial). All remains are from the Rhaetian of Autun area.

Plesiosaurus costatus: PLV 1935 (vertebra); PLV 1955 (vertebra).

Actiosaurus gaudryi (PLV 1937, PLV 1944), two propodials resembling those of choristoderes (e.g. Storrs and Gower 1993).

\section{Discussion}

Several lines of evidence presented in the comparative descriptions above indicate that the Cuers and Autun localities contain an ichthyosaur assemblage dominated by large shastasaurid-like forms. Discrepancies in sizes (e.g. the small femur PLV 1963, the moderately-sized scapula PLV 1942 and the very large ilium PLV 1940 and the centra PLV 1949 partim and PLV 10bis) indicate the presence of multiple individuals in Autun, and possibly distinct taxa. Although rare in Europe (Callaway and Massare 1989), the presence of shastasaurid-like ichthyosaurs in northwestern Tethys is not surprising from a biogeographic point of view, as this group was one of the first ichthyosaur clades to attain a very broad biogeographic range, colonizing both Tethys and Panthalassa (Callaway and Massare 1989; Sander 1997; Motani et al. 1999; Ji et al. 2010; Bardet et al. 2014). However, shastasaurids and shastasaurid-like ichthyosaurs (depending on taxonomic opinions) were hitherto restricted to the Anisian-middle Norian interval (Callaway and Massare 1989; McGowan and Motani 2003; Nicholls and Manabe 2004; Ji et al. 2010). The specimens from Cuers and Autun therefore represent the youngest record of that group and morphotype and imply a substantial range extension to the latest stage of the Triassic. Interestingly, Storrs (1994) reported the presence of very large centra, matching those of Shonisaurus sikanniensis, in Rhaetian strata of England. Further sampling may thus reveal additional occurrences of shastasaurid-like forms in latest Triassic strata. Rather than representing a genuine biological signal, the supposed Norian demise of shastasaurids was thus at least partially biased by a decrease of the quality of the fossil record. Although the record of Rhaetian ichthyosaurs is still too poorly sampled, our new data unambiguously indicate this group reached the end of the Triassic, dominating the French Rhaetian marine ecosystems. Combined with the recent discovery of a possible shastasaurid-like ichthyosaur in the lowermost Jurassic of Wales (Martin et al. In Press), our new data suggest that the extinction of the peculiar, gigantic shastasaurid-like ichthyosaurs forms a 
new facet of the Triassic-Jurassic mass extinction, which was probably not an instantaneous catastrophic event like often postulated for the K-Pg extinction.

An equally unexpected feature of Cuers and Autun assemblages is the absence of remains compatible with neoichthyosaurians, giving these assemblages a typically 'Triassic' aspect. Small remains appear generally rare in Autun, possibly because of a depositional bias; this may alter the fossil record towards large taxa. Yet, we do not expect the lack of neoichthyosaurians to be due to this bias, as early neoichthyosaurians are generally large forms (e.g. Leptonectes, Temnodontosaurus and some specimens of Ichthyosaurus: McGowan 1989; Godefroit 1993; McGowan 1996a; Maisch et al. 2008; Martin et al. 2012). By contrast, the earliest Jurassic of Western Europe contains an extremely rich record of neoichthyosaurians from distinct lineages (e.g. McGowan 1974b, a; Maisch 1999). Neoichthyosauria thus probably arose elsewhere (its sister taxa are from the Norian of British Columbia: McGowan 1995, 1996b; Motani 1999) and massively colonized Western Europe during or after the end-Triassic events. From a global point of view, the current data indicates that both the disappearance of a significant part of the Late Triassic ichthyosaur diversity and disparity (carried by shastasaurid-like forms; Thorne et al. 2011) and the rapid radiation of Neoichthyosauria (Fischer et al. 2013) are restricted to the Rhaetian stage, which is about 7.2 Ma in duration (Gradstein et al. 2012) and form a rather short-lived turnover that profoundly affected the evolutionary history of ichthyosaurs.

Other marine reptile clades, placodonts and thalattosaurs (Müller 2007; Kelley et al. 2014), went totally extinct during the Rhaetian; numerous invertebrate groups were also affected (e.g. Hallam and Wignall 1997; Wignall and Bond 2008; Smith et al. 2014). But other groups such as plesiosaurs and neoichthyosaurians radiated immediately after (Benson et al. 2012; Fischer et al. 2013), implying a Rhaetian or older divergence of lineages. Under this revised scheme, the Rhaetian and the TriassicJurassic boundary therefore concentrate a massive faunal turnover for marine reptiles. Severe environmental changes have also been reported in the same interval, notably a meteorite impact (Olsen et al. 2002; Smit et al. 2014) and flood volcanism (Schoene et al. 2010; Whiteside et al. 2010). However, precise stratigraphic correlation in between all these biotic events and between the biotic and abiotic events is still wanting (see reviews of Hesselbo et al. 2002; Deenen et al. 2010; Van de Schootbrugge et al. 2013). On the other hand, close analyses reveal that many groups, especially among invertebrates and microvertebrates, have a rather diffuse, non-catastrophic Late Triassic turnover characterized by elevated extinction rates during the entire Norian-Rhaetian interval (Cuny 1995; Tanner et al. 2004; Bambach 2006; Mander et al. 2008). While our data modifies our understanding of the Late Triassic history of ichthyosaurs, it also leave an open question: is the entire extinction of shastasaurid-like forms a severe event restricted to the Triassic-Jurassic boundary or did it happen as a series of minor extinctions from the Norian to the earliest Jurassic? What appears currently clear is that this extinction and its context are more complex than previously postulated and that the final demise of shastasaurid-like ichthyosaurs may likely be a supplementary facet of the endTriassic mass extinction.

\section{Acknowledgments}

S.G. and V.F. are grateful to P. Van Peer, R. Speijer and A. van Baelen (K.U. Leuven) for access to the paleontological collections currently under their care. We also thank W. Van Neer and M. CoenAubert (Royal Belgian Institute of Natural Sciences, Belgium) for supplying valuable information on the history of the Leuven collections. G.G. and X.V. thank our colleagues L. Villiers (Université Pierre et Marie Curie, France) who allows us to consult the collections of Derognat (University StCharles, Marseille, France) and M. Schuster (University of Strasbourg) for scientific discussions concerning the sedimentology of the Cuers section. The reptile material from Cuers was prepared at the University of Poitiers. We thank also P. Orsini, F. Dussoulier and S. Giner (Natural History 
Museum of Toulon) for accepting the deposit of the ichthyosaur specimens from Cuers and interest in the project. We also thank three anonymous reviewers and editor S. Thatje for helping us improving this manuscript.

\section{References}

Agassiz L (1833-43) Recherches sur les poissons fossiles. vol 3, 1420 pp. Neuchâtel et Soleure, Petitpierre,

Bakker RT (1993) Plesiosaur Extinction Cycles — Events that Mark the Beginning, Middle and End of the Cretaceous. In: Caldwell WGE, Kauffman EG (eds) Evolution of the Western Interior Basin: Geological Association of Canada, Special Paper, vol 39. Stittsville, Ontario, Canada, pp 641-664

Bambach RK (2006) Phanerozoic biodiversity mass extinctions. Annual review of Earth and Planetary Sciences 34:127-155

Bardet N (1992) Stratigraphic evidence for the extinction of the ichthyosaurs. Terra Nova 4:649-656

Bardet N (1994) Extinction events among Mesozoic marine reptiles. Hist Biol 7:313-324

Bardet N, Cuny G (1993) Triassic reptile faunas from France. Paleontologia Lombarda nuova serie 2:9-18

Bardet N, Falconnet J, Fischer V, Houssaye A, Jouve S, Pereda Suberbiola X, Pérez-García A, Rage J$\mathrm{C}$, Vincent $\mathrm{P}$ (2014) Mesozoic marine reptile palaeobiogeography in response to drifting plates. Gondwana Research 26:869-887. doi:10.1016/j.gr.2014.05.005

Benson RB, Evans M, Druckenmiller PS (2012) High diversity, low disparity and small body size in plesiosaurs (Reptilia, Sauropterygia) from the Triassic-Jurassic boundary. PLoS ONE 7 (3): $\mathrm{e} 31838$

Blainville HMD, de (1835) Description de quelques espèces de reptiles de la Californie, précédée de l'analyse d'un système général d'érpetologie et d'amphibiologie. Nouvelles annales du Muséum d'Histoire naturelle, Paris 4:233-296

Buchholtz EA (2001) Swimming styles in Jurassic ichthyosaurs. J Vertebr Paleontol 21 (1):61-73

Callaway JM, Massare J (1989) Geographic and stratigraphic distribution of the Triassic Ichthyosauria (Reptilia; Diapsida). Neues Jahrb Geol Palaontol-Abh 178:37-58

Camp CL (1980) Large ichthyosaurs from the Upper Triassic of Nevada. Paläontographica, Abteilung A 170:139-200

Cappetta H (2012) Chondrichthyes (Mesozoic and Cenozoic Elasmobranchii: teeth). Handbook of Paleoichthyology, vol 3E, 512 pp. Verlag F. Pfeil,

Caron JPH (1967) Etude stratigraphique du Muschelkalk supérieur calcaire et dolomitique de BasseProvence occidentale entre Bandol et Hyères (Var). Bulletin de la Société Géologique de France, septième série 9 (670-677)

Charles RP (1948) Note paléontologique sur le Trias de Provence. Bulletin de la Société Géologique de France, cinquième série 18:475-483

Corroy G (1933) Les poissons et les reptiles du Muschelkalk et du Rhétien de Basse-Provence. Bulletin de la Société Géologique de France, cinquième série 3 (5-6):475-483

Cuny G (1995) French vertebrate faunas and the Triassic-Jurassic boundary. Palaeogeogr Palaeoclimatol Palaeoecol 119:343-358

Dal Sasso C, Pinna G (1996) Besanosaurus leptorhynchus n. gen. n. sp., a new Shastasaurid ichthyosaur from the Middle Triassic of Besano (Lombardy, N. Italy). Paleontologia Lombarda nuova serie 4:. 23

Dalla Vecchia FM, Avanzini M (2002) New findings of isolated remains of Triassic reptiles from Northeastern Italy. Bollettino della Societa Paleontologica Italiana 41 (2-3):215-235 
Deenen MHL, Ruhl M, Bonis NR, Krijgsman W, Kuerschner WM, Reitsma M, van Bergen MJ (2010) A new chronology for the end-Triassic mass extinction. Earth and Planetary Science Letters 291:113-125

Delsatte D, Lepage JC (1991) Requins et raies en Lorraine. Geolor 3:6-9

Duffin CJ (1993) Late Triassic shark teeth (Chondrichthyes, Elasmobranchii) from Saint-Nicolas-dePort (north-east France). In: Herman J, Van Waes H (eds) Elasmobranches et Stratigraphie, vol 264. Belgian Geological Survey, Professional Paper, pp 7-32

Duffin CJ (1998) New shark remains from the British Rhaetian (latest Triassic). 1. The earliest basking shark. Neues Jahrbuch für Geologie und Paläontologie, Monatshefte 3:157-181

Duffin CJ, Delsatte D (1993) The age of the Upper Triassic vertebrate fauna from Attert (Province of Luxembourg, Belgium). In: Herman J, Van Waes H (eds) Elasmobranches et Stratigraphie, vol 264. Belgian Geological Survey, Professional Paper, pp 33-44

Fischer V, Appleby RM, Naish D, Liston J, Riding JB, Brindley S, Godefroit P (2013) A basal thunnosaurian from Iraq reveals disparate phylogenetic origins for Cretaceous ichthyosaurs. Biology Letters 9 (20130021):1-6. doi:10.1098/rsbl.2013.0021

Fischer V, Bardet N, Guiomar M, Godefroit P (2014) High Diversity in Cretaceous Ichthyosaurs from Europe Prior to Their Extinction. PLoS ONE 9 (1):e84709. doi:10.1371/journal.pone.0084709

Fischer V, Maisch MW, Naish D, Liston J, Kosma R, Joger U, Krüger FJ, Pardo-Pérez J, Tainsh J, Appleby RM (2012) New ophthalmosaurids from the Early Cretaceous of Europe demonstrate extensive ichthyosaur survival across the Jurassic-Cretaceous boundary. PLoS ONE 7 (1):e29234. doi:10.1371/journal.pone.0029234

Fröbisch NB, Fröbisch J, Sander PM, Schmitz L, Rieppel O (2013) Macropredatory ichthyosaur from the Middle Triassic and the origin of modern trophic networks. Proceedings of the National Academy of Sciences. doi:10.1073/pnas. 1216750110

Gand G, Bourillot R, Brigaud B, Steyer J-S, Peyrouse J-B (2012) Les Reptiles et Synapsides fossiles de Bourgogne. Revue Scientifique Bourgogne-Nature, Hors-Série 12 (23-86)

Godefroit P (1993) Les grands ichthyosaures sinémuriens d'Arlon. Bull Inst R Sci Nat Belg Sci Terre 63:25-71

Gradstein FM, Ogg JG, Schmitz M, Ogg G (2012) The Geologic Time Scale 2012. 1176 pp. Elsevier Science \& Technology, Oxford, Great Britain

Hallam A, Wignall PB (1997) Mass Extinctions and their Aftermath. pp. Oxford University Press, New York

Hautmann M (2001) Taxonomy and phylogeny of cementing Triassic bivalves (families Prospondylidae, Plicatulidae, Dimyidae and Ostreidae). Palaeontology 44 (2):339-373. doi:10.1111/1475-4983.00183

Hesselbo SP, Robinson SA, Surlyk F, Piasecki S (2002) Terrestrial and marine extinction at the Triassic-Jurassic boundary synchronized with major carbon-cycle perturbation: A link to initiation of massive volcanism? Geology 30 (3):251-254. doi:10.1130/00917613(2002)030<0251:tameat $>2.0 . c 0 ; 2$

Huene Fv (1902) Übersicht über die Reptilien der Trias. Geologische und Paläontologische Abhandlungen (Neue Serie) 6:1-84

Ji C, Jiang D-Y, Motani R, Hao W-C, Sun Y-L (2010) Phylogenetic analysis of Shastasauridae illuminated by Guizhouichthyosaurus from China indicates a possible pathway of the migration of this family. J Vert Paleo Prog Abs 2010:111A

Ji C, Jiang D-Y, Motani R, Hao W-C, Sun Z-Y, Cai T (2013) A new juvenile specimen of Guanlingsaurus (Ichthyosauria, Shastasauridae) from the Upper Triassic of southwestern China. J Vertebr Paleontol 33 (2):340-348. doi:10.1080/02724634.2013.723082 
Johnson R (1977) Size independent criteria for estimating relative age and the relationship among growth parameters in a group of fossil reptiles (Reptilia: Ichthyosauria). Can J Earth Sci 14:1916-1924

Kelley NP, Motani R, Jiang D-y, Rieppel O, Schmitz L (2014) Selective extinction of Triassic marine reptiles during long-term sea-level changes illuminated by seawater strontium isotopes. Palaeogeogr Palaeoclimatol Palaeoecol 400:9-16. doi:10.1016/j.palaeo.2012.07.026

Kolb C, Sander PM (2009) Redescription of the ichthyosaur Platypterygius hercynicus (Kuhn 1946) from the Lower Cretaceous of Salzgitter (Lower Saxony, Germany). Palaeontogr Abt A Palaeozool-Stratigr 288 (4-6):151-192

Lucas SG (2002) Toretocnemus, a Late Triassic ichthyosaur from California, U.S.A. and Sonora, Mexico. New Mexico Museum of Natural History and Science Bulletin 21:275-278

Maisch MW (1998) A new ichthyosaur genus from the Posidonia Shale (Lower Toarcian, Jurassic) of Holzmaden, SW-Germany with comments on the phylogeny of post-Triassic ichthyosaurs. Neues Jahrb Geol Palaontol-Abh 209 (1):47-78

Maisch MW (1999) Leptonectiden und Temnodontosauriden (Ichthyosauria) aus dem AlphaÖlschiefer (Sinemurium) von Baden-Württemberg (SW-Deutschland). Neues Jahrbuch für Geologie und Paläontologie Monatshefte 8:490-512

Maisch MW (2002) Observations on Triassic ichthyosaurs; Part IX, The first associated skeletal remains of Merriamosaurus n. g. (Ichthyosauria, Lower Triassic) and their bearing on the systematic position of the Omphalosauria. Neues Jahrbuch für Geologie und Paläontologie. Abhandlungen, vol 226. E. Schweizerbart'sche Verlagsbuchhandlung : Stuttgart, Federal Republic of Germany, Federal Republic of Germany

Maisch MW (2010) Phylogeny, systematics, and origin of the Ichthyosauria - the state of the art. Palaeodiversity 3:151-214

Maisch MW, Matzke AT (2000) The Ichthyosauria. Stuttg Beitr Natkd Ser B (Geol Palaeontol) 298:1-159

Maisch MW, Reisdorf A, Schlatter R, Wetzel A (2008) A large skull of Ichthyosaurus (Reptilia: Ichthyosauria) from the Lower Sinemurian (Lower Jurassic) of Frick (NW Switzerland). Swiss Journal of Geoscience 101 (3):617-627

Mander L, Twitchett RJ, Benton MJ (2008) Palaeoecology of the Late Triassic extinction event in the SW UK. Journal of the Geological Society 165 (1):319-332. doi:10.1144/0016-76492007-029

Martin JE, Fischer V, Vincent P, Suan G (2012) A longirostrine Temnodontosaurus (Ichthyosauria) with comments on Early Jurassic ichthyosaur niche partitioning and disparity. Palaeontology 55 (5):995-1005. doi:10.1111/j.1475-4983.2012.01159.x

Martin JE, Vincent P, Suan G, Sharpe T, Hodges P, Williams M, Howels C, Fischer V (In Press) A mysterious giant ichthyosaur from the lowermost Jurassic of Wales. Acta Palaeontol Pol. doi:10.4202/app.00062.2014

Maxwell EE, Zammit M, Druckenmiller PS (2012) Morphology and orientation of the ichthyosaurian femur. J Vertebr Paleontol 32 (5):1207-1211. doi:10.1080/02724634.2012.682834

McGowan C (1974a) A revision of the latipinnate ichthyosaurs of the Lower Jurassic of England (Reptilia, Ichthyosauria). Life Science Contributions, Royal Ontario Museum 100:1-30

McGowan C (1974b) A revision of the longipinnate ichthyosaurs of the Lower Jurassic of England, with description of the new species (Reptilia, Ichthyosauria). Life Science Contributions, Royal Ontario Museum 97:1-37

McGowan C (1989) Leptopterygius tenuirostris and other long-snouted ichthyosaurs from the English Lower Lias. Palaeontology 32 (3):409-427

McGowan C (1994) A new species of Shastasaurus (Reptilia: Ichthyosauria) from the Triassic of British Columbia; the most complete exemplar of the genus. J Vertebr Paleontol 14:168-179 
McGowan C (1995) A remarkable small ichthyosaur from the Upper Triassic of British Columbia, representing a new genus and species. Can J Earth Sci 32:292-303

McGowan C (1996a) Giant ichthyosaurs of the Early Jurassic. Can J Earth Sci 33 (7):1011-1021

McGowan C (1996b) A new and typically Jurassic ichthyosaur from the Upper Triassic of Birtish Columbia. Can J Earth Sci 33 (24-32)

McGowan C (1997) A Transitional Ichthyosaur Fauna. In: Callaway JM, Nicholls EL (eds) Ancient Marine Reptiles. Academic Press, San Diego, California, pp 61-80

McGowan C (2003) A new specimen of Excalibosaurus from the English Lower Jurassic. J Vertebr Paleontol 23 (4):950-956

McGowan C, Motani R (1999) A Reinterpretation of the Upper Triassic ichthyosaur Shonisaurus. J Vertebr Paleontol 19 (1):42-49

McGowan C, Motani R (2003) Part 8. Ichthyopterygia. Handbook of Paleoherpetology, vol 8, 175 pp. Verlag Dr. Friedrich Pfeil, München

Merriam JC (1902) Triassic Ichthyopterygia from California and Nevada. University of California Publications: Bulletin of the department of Geology 3 (4):63-108

Merriam JC (1908) Triassic Ichthyosauria with special reference to the American forms. Memoirs of the University of California 1:1-154

Motani R (1997) Temporal and Spatial Distribution of Tooth Implantation in Ichthyosaurs. In: Callaway JM, Nicholls EL (eds) Ancient Marine Reptiles. Academic Press, San Diego, California, pp 81-103

Motani R (1999) Phylogeny of the Ichthyopterygia. J Vertebr Paleontol 19 (3):473-496

Motani R, Manabe M, Dong Z-M (1999) The status of Himalayasaurus tibetensis (Ichthyopterygia). Paludicola 2:174-181

Müller J (2007) First record of a thalattosaur from the Upper Triassic of Austria. J Vertebr Paleontol 27 (1):236-240. doi:10.1671/0272-4634(2007)27[236:FROATF]2.0.CO;2

Nicholls EL, Manabe M (2001) A new genus of ichthyosaur from the Late Triassic Pardonet Formation of British Columbia : bridging the Triassic-Jurassic gap. Can J Earth Sci 38:9831002

Nicholls EL, Manabe M (2004) Giant ichthyosaurs of the Triassic-A new species of Shonisaurus from the Pardonet Formation (Norian: Late Triassic) of British Columbia. J Vertebr Paleontol 24 (4):838-849

Olsen PE, Kent DV, Sues H-D, Koeberl C, Huber H, Montanari A, Rainforth EC, Fowell SJ, Szajna MJ, Hartline BW (2002) Ascent of dinosaurs linked to an iridium anomaly at the TriassicJurassic boundary. Science 296 (5571):1305-1307. doi:10.1126/science.1065522

Quenstedt FA (1856-1858) Der Jura. 842 pp., Tübingen (Laupp)

Sander PM (1989) The large ichthyosaur Cymbospondylus buchseri, sp. nov., from the Middle Triassic of Monte San Giorgio (Switzerland), with a survey of the genus in Europe. Journal of Vertebrate Paleontology, vol 9. University of Oklahoma : Norman, OK, United States, United States

Sander PM (1997) The paleobiogeography of Shastasaurus. In: Callaway JM, Nicholls EL (eds) Ancient Marine Reptiles. Academic Press, San Diago, California, San Diego California, pp $17-43$

Sander PM, Chen X, Cheng L, Wang X (2011) Short-snouted toothless ichthyosaur from China suggests Late Triassic diversification of suction feeding ichthyosaurs. PLoS ONE 6 (5): 19480

Sauvage HE (1876) Note sur les débris d'ichthyosaure des couches rhétiennes de Saône-et-Loire. Annales des Sciences Géologiques 7 (Article 6):1-1 
Sauvage HE (1883) Recherches sur les reptiles trouvés dans l'étage rhétien des environs d'Autun. Annales des Sciences Géologiques 14 (6, article n³):1-44

Sauvage HE (1903) Note sur les reptiles de l'étage Rhétien des environs d'Autun. Bulletin de la Société d'Histoire naturelle d'Autun 16:309-318

Schoene B, Guex J, Bartolini A, Schaltegger U, Blackburn TJ (2010) Correlating the end-Triassic mass extinction and flood basalt volcanism at the $100 \mathrm{ka}$ level. Geology 38 (5):387-390. doi: $10.1130 / \mathrm{g} 30683.1$

Shang Q-H, Li C (2009) On the occurence of the ichthyosaur Shastasaurus in the Guanling biota (Late Triassic), Guizhou, China. Vertebrata PalAsiatica 47 (3):178-193

Smit J, Kyte F, de Graaff SJ, Jansen MN, de Raad FM (2014) Iridium anomaly at the Triassic-Jurassic (TrJ) mass-extinction event in Canj, Montenegro: Evidence for extraterrestrial rather than terrestrial cause. Geophysical Research Abstracts 16 (EGU2014-5560-3):1

Smith PL, Longridge LM, Grey M, Zhang J, Liang B (2014) From near extinction to recovery: Late Triassic to Middle Jurassic ammonoid shell geometry. Lethaia 47 (3):337-351. doi:10.1111/let.12058

Storrs GW (1994) Fossil vertebrate faunas of the Birtish Rhaetian (latest Triassic). Zool J Linn Soc 112:217-259

Storrs GW, Gower DJ (1993) The earliest possible choristodere (Diapsida) and gaps in the fossil record of semi-aquatic reptiles. J Geol Soc London 150:1103-1107

Sykes JH (1971) A new Dalatiid fish from the Rhaetic bone-bed at Barnstone, Nottinghamshire. The Mercian Geologist 4:13-22

Tanner L, Lucas S, Chapman M (2004) Assessing the record and causes of Late Triassic extinctions. Earth-Science Reviews 65:103-139

Thorne PM, Ruta M, Benton MJ (2011) Resetting the evolution of marine reptiles at the TriassicJurassic boundary. Proc Natl Acad Sci U S A 108 (20):8339-8344. doi:10.1073/pnas.1018959108

Van de Schootbrugge B, Bachan A, Suan G, Richoz S, Payne JL (2013) Microbes, mud and methane: Cause and consequence of recurrent early Jurassic anoxia following the end-Triassic mass extinction. Palaeontology 56 (4):685-709

Whiteside JH, Olsen PE, Eglinton T, Brookfield ME, Sambrotto RN (2010) Compound-specific carbon isotopes from Earth's largest flood basalt eruptions directly linked to the end-Triassic mass extinction. Proceedings of the National Academy of Sciences 107:6721-6725. doi:10.1073/pnas.1001706107

Wignall PB, Bond DPG (2008) The end-Triassic and Early Jurassic mass extinction records in the British Isles. Proc Geol Assoc 119 (1):73-84. doi:http://dx.doi.org/10.1016/S00167878(08)80259-3

Zapfe H (1976) Ein großer Ichthyosaurier aus den Kössener Schichten der Nordalpen. Annalen des Naturhistorischen Museums in Wien 80:239-250 


\section{Electronic Supplementary material}

\section{Research history of the material from Autun}

The Pellat collection refers to Edmont Pellat ( ${ }^{\circ}$ July 19th 1832 - †July 10th 1907), a celebrated French amateur paleontologist who gathered his enormous collection of fossils during numerous travels throughout France and Algeria during his career. Having frequent contacts with scientists, a large number of his specimens were chosen as type specimens for vertebrate and invertebrate taxa. Pellat amassed a collection of Rhaetian vertebrates gathered by quarrymen from the Autun area (Gand et al. 2012). Sauvage $(1876,1883)$ established five taxa based on this material: Ichthyosaurus rheticus, Ichthyosaurus carinatus, Rachitrema pellati, Actiosaurus gaudryi, and Plesiosaurus bibractensis. These taxa were variously considered as ichthyosaurs, plesiosaurs, theropods, and therapsids (Huene 1902; Sauvage 1903; McGowan and Motani 2003).

By intermittences of the 'comptoir géologique les fils d' E. Deyrolles' (Paris), the Pellat collection was, after his death, sold to Henri de Dorlodot ( ${ }^{\circ}$ August $15^{\text {th }}, 1855-\dagger$ January $\left.4^{\text {th }}, 1929\right)$, professor in geology and paleontology at the K.U. Leuven, for a sum of 41,417 francs. At first, the name of the buyer was kept secret, as requested by the family. The sale and more importantly the possibility that the collection left France created a lot of fuzz (Burnotte 1985). But according to several documents, the K.U. Leuven was preferred by E. Pellat himself and his family (see Burnotte 1985 for a detailed account).

Some years before, in 1904, a part of the collection of the French geologist Eugène Dumortier (1801-1876) arrived at the K.U. Leuven. The precise details about the sale were not recovered, but the university archives note the intermediary of Adolphe Piret, head of the 'comptoir belge de minéralogie et de paléontologie' at Tournai (Belgium) (Burnotte 1985). A substantial part of the Dumortier collection, containing vertebrates and invertebrates fossils, was donated to the Université de Lyon, France. Sauvage's types from the Pellat and Dumortier went to the fossil vertebrate collections of K.U. Leuven. For more than a century, these specimens remained in the K.U. Leuven collections, surviving both the bombing of Leuven in the 1st and 2nd world wars, and two consecutive relocations (late 60ies and 2005). In the mean time, these specimens and their associated taxa disappeared from the literature. It was by accident that S.G. and V.F. relocated the specimens in 2012.

Table S1 Tooth implantation modes of shastasaurid-like ichthyosaurs. Edentulous refers to a complete absence of alveoli, dental groove, and bony fixation. The taxonomy of Shastasaurus follows

McGowan 1994. The asterisk (*) indicates that specimen was firstly described as Shastasaurus altispinus by Callaway \& Massare (1989b), but referred to Shonisaurus sp. by Motani (1999).

\begin{tabular}{lll}
\hline Taxon or specimen & Tooth implantation & Reference \\
\hline ROM 44296 & subthecodont? & McGowan 1997 \\
$\begin{array}{l}\text { Besanosaurus leptorhynchus } \\
\text { Shastasaurus pacificus }\end{array}$ & thecodont & Dal Sasso and Pinna 1996 \\
Guanlingsaurus liangae & aulacodont & Motani 1997; Maisch and \\
& edentulous & Sander et al. 2011 \\
Shastasaurus sikanniensis & edentulous & Nicholls and Manabe 2004; \\
& & Sander et al. 2011 \\
Shonisaurus popularis & thecodont & Camp 1980; McGowan 1997; \\
& & Motani 1997; McGowan and \\
Shonisaurus popularis & thecodont in juveniles, & Motani 1999 \\
& edentulous in adults & Nicholls and Manabe 2004
\end{tabular}


Shonisaurus sp. (UCMP 27141)*

Himalayasaurus tibetensis

"Callawayia" neoscapularis

"Callawayia" neoscapularis

Guizhouichthyosaurus tangae thecodont

Callaway and Massare 1989a

? (ridges)

Motani 1997; Motani et al. 1999

aulacodont

McGowan 1994; Motani 1997

subthecodont

Nicholls and Manabe 2001

thecodont

Maisch et al. 2006 


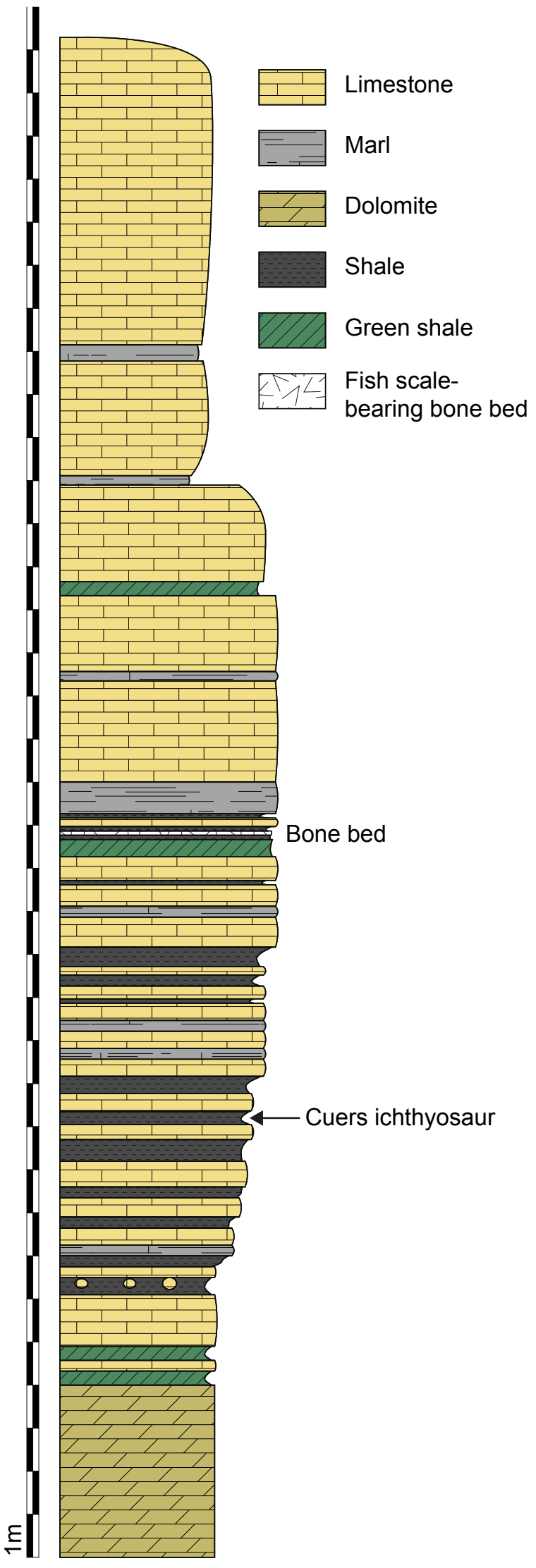

Fig. S1 Stratigraphic log of the discovery site of the Cuers ichthyosaur, in Saint-Laurens, Var, France, surveyed by X.V. 


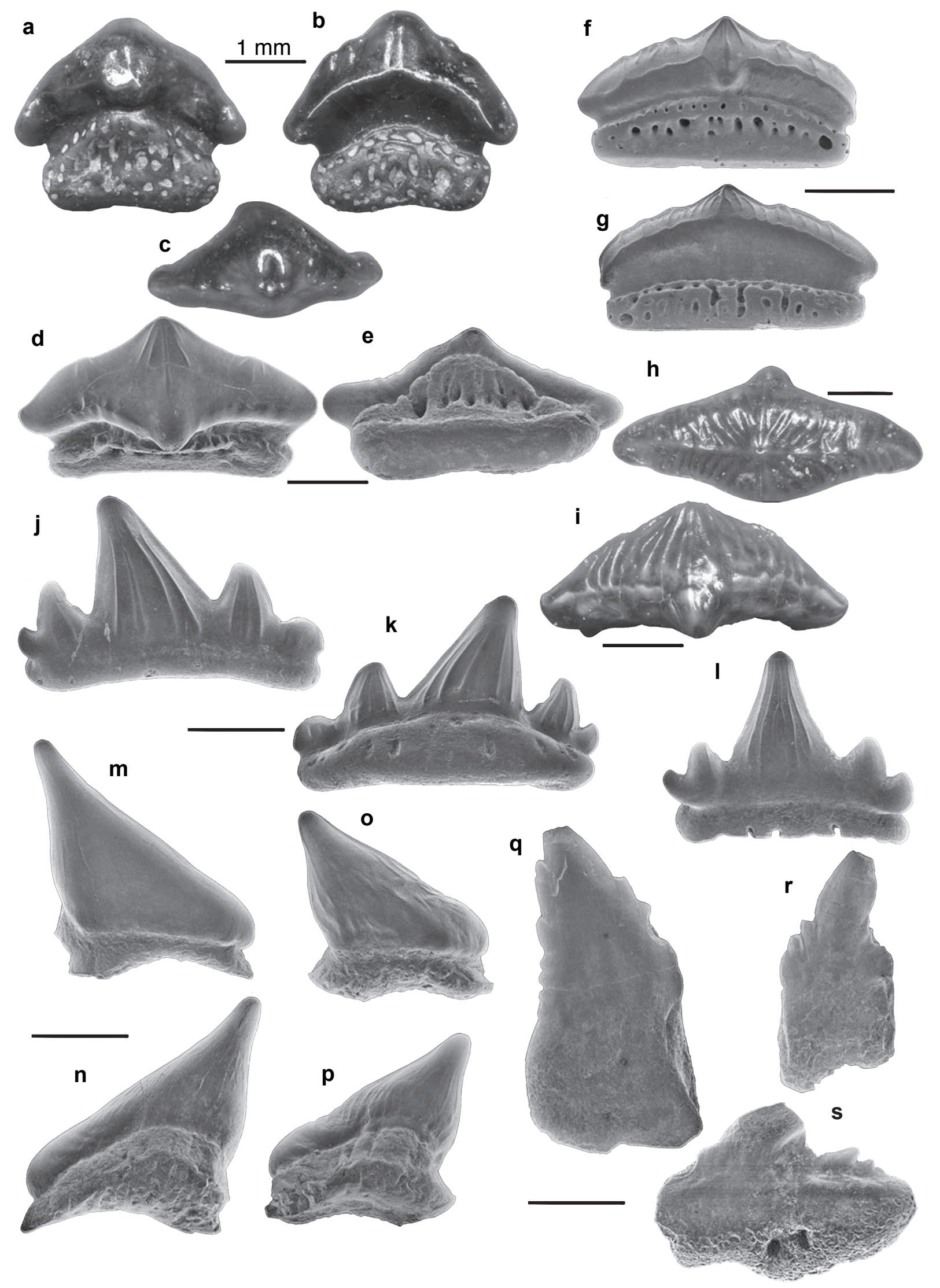

Fig. S2 Stratigraphically relevant elasmobranchs from the Saint-Laurens site. a-i, Lissodus minimus; a-c, anterior tooth, UM-CUE 3; a, labial view; b, lingual view; c, occlusal view; d-e, anterolateral tooth, UM-CUE 4; d, labial view; e, basal view; f-g, anterolateral tooth, UM-CUE 5; f, labial view; $\mathbf{g}$, lingual view; $\mathbf{h}$, lateral tooth, UM-CUE 6, occlusal view; i, lateral tooth, UM-CUE 7, labial view; $\mathbf{j}-\mathbf{1}$, 
Rhomphaiodon nicolensis; $\mathbf{j}-\mathbf{k}$, upper antero-lateral tooth, UM-CUE 8; $\mathbf{j}$, labial view; $\mathbf{k}$, lingual view; l, lower lateral tooth, UM-CUE 9, labial view; m-p, Pseudocetorhinus pickfordi; m-n, antero-lateral tooth, UM-CUE 10; m, labial view; N, lingual view; o-p, more lateral tooth, UM-CUE 11; o, labial view; $\mathbf{p}$, lingual view; q-s, Pseudodalatias barnstonensis; $\mathbf{q}$, lower anterior tooth, UM-CUE 12, labial view; r, lower lateral tooth, UM-CUE 13, lingual view; s, very lateral tooth, UM-CUE 14, lingual view. Scale bars $=1 \mathrm{~mm}$. 
a
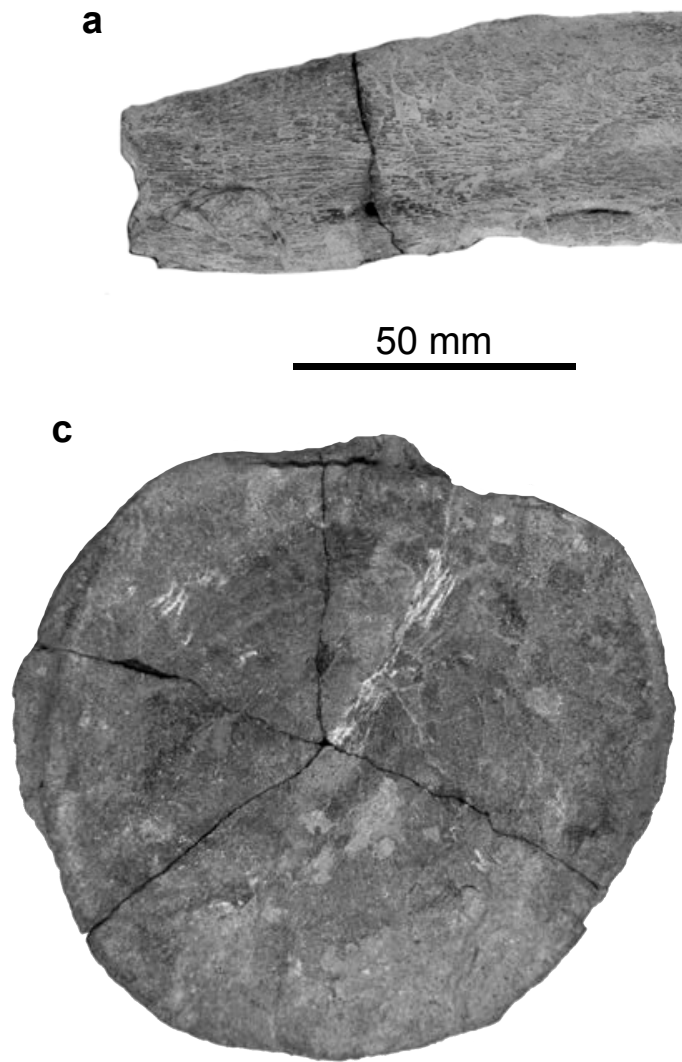

d

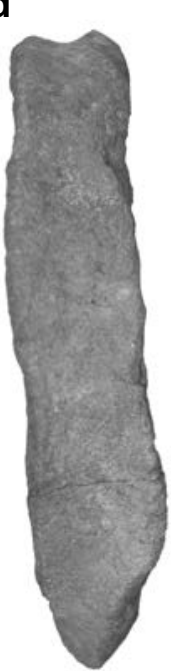

b

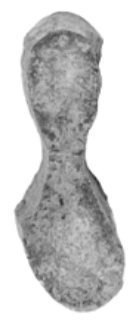

f

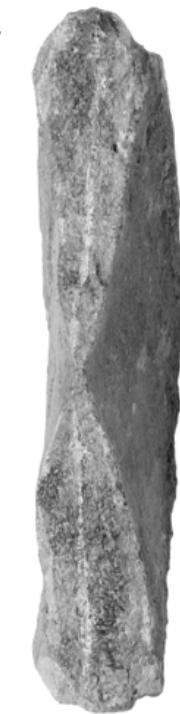

Fig. S3 Axial skeleton remains from the Cuers ichthyosaur. a, distal end of a rib (MHNTV PAL$2 / 2010$ ). $\mathbf{b}$, cross-section of the proximal part of $\mathbf{a}$; note the conspicuous ' 8 '-shaped cross-section. $\mathbf{c}$, centrum (MHNTV PAL-1_10/2012) in anterior view. d, centrum (MHNTV PAL-1_10/2012) in lateral view. e, centrum (MHNTV PAL-2/2010) in anterior view. f, centrum (MHNTV PAL-2/2010) in medial view. 

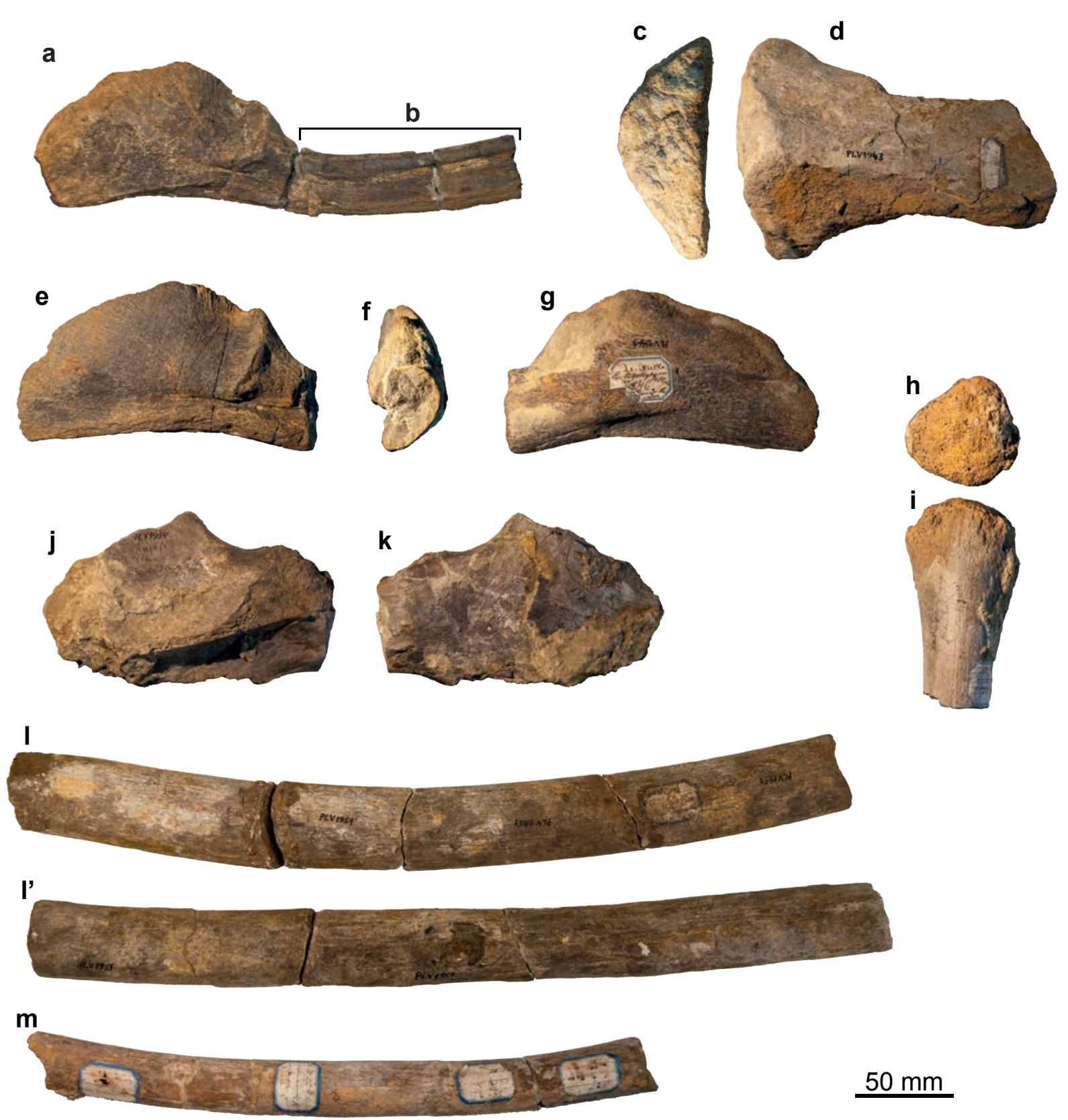

$50 \mathrm{~mm}$

Fig. S4 Other remains from the Rachitrema pellati type series. a, PLV 1950 possible posterior of a mandible in medial view, that connects to PLV 1959 (b), a indeterminate bone regarded by Sauvage as belonging to Ichthyosaurus rheticus. c-d, PLV 1943, a possible ichthyosaur coracoid severely weathered in c, medial; d, anterior views. e-f, PLV 1941, a fragmentary bone similar to but larger than PLV 1950 (a), in e, medial; f, anterior; g, lateral views. h-i, PLV 1938, a partial sauropterygian propodial in h, capitular; $\mathbf{i}$, anterior views. $\mathbf{j}$-k, PLV 1934, probable posterior part of an ichthyosaur surangular in j, medial; k, lateral views. l-l', PLV 1951, a probable ichthyosaur rib or gastralia of very large size. m, PLV 1952, a probable ichthyosaur rib or gastralia. 

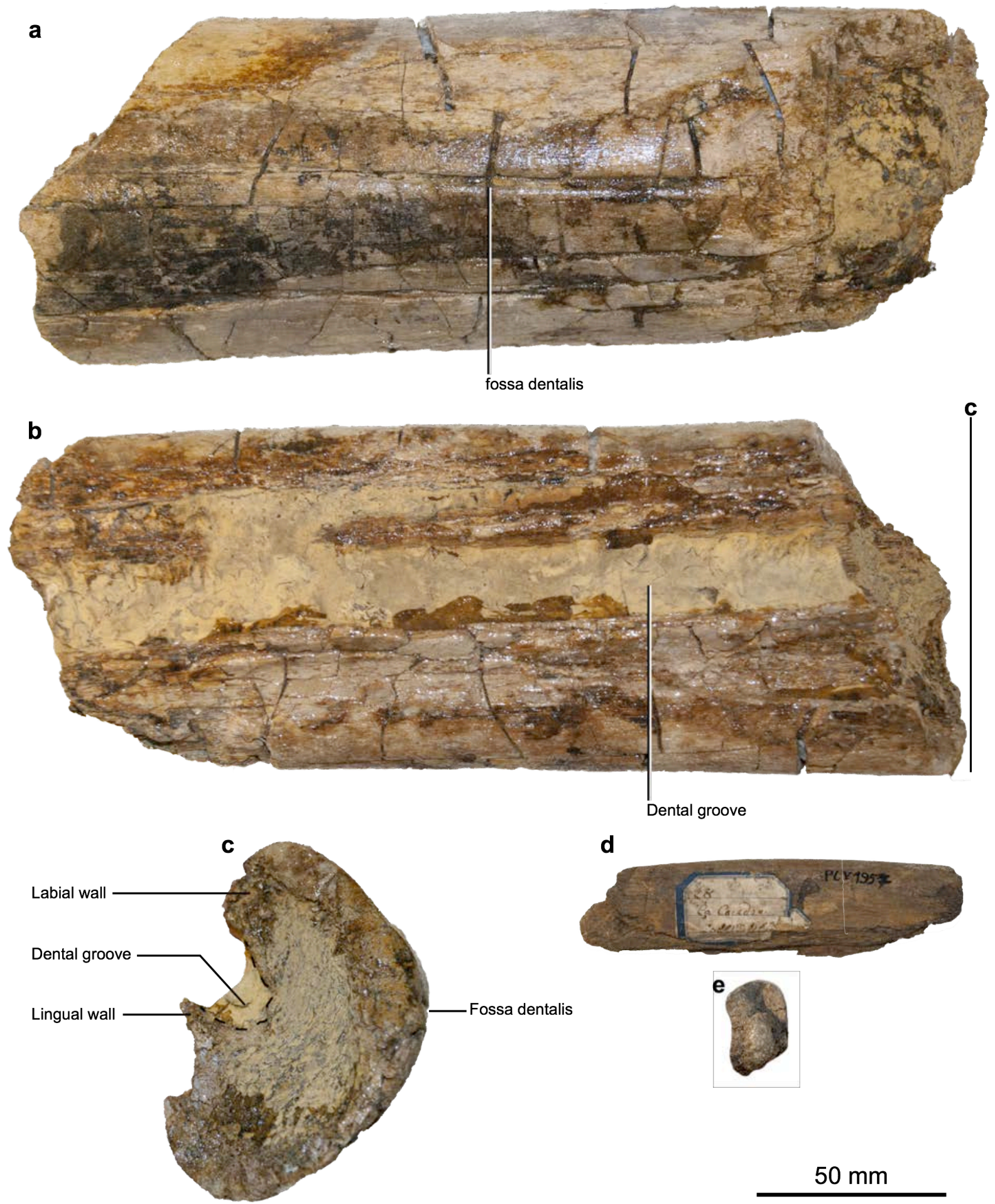

Fig. S5 Remains compatible with the series of Ichthyosaurus carinatus. a-c mandible fragment in a, lateral; b, medial; c, posterior views. Note the lateral fossa dentalis and medial dental groove. A similar condition is found in the original material of Sauvage (1883) and in the Cuers ichthyosaur. d, e, rib fragment labeled as Ichthyosaurus carinatus, in d, lateral view; e, cross-section.

\section{References}

Burnotte G (1985) Le rôle de Henri de Dorlodot dans la fondation de l'Institut de Géologie de l'Université Catholique de Louvain. Unpublished thesis., Université Catholique de Louvain, Leuven, Belgium

Callaway JM, Massare J (1989a) Geographic and stratigraphic distribution of the Triassic Ichthyosauria (Reptilia; Diapsida). Neues Jahrb Geol Palaontol-Abh 178:37-58 
Callaway JM, Massare J (1989b) Shastasaurus altispinus (Ichthyosauria: Shastasauridae) from the Upper Triassic of El Antimonio district, Northwestern Sonora, Mexico. J Paleontol 63 (6):930-939

Camp CL (1980) Large ichthyosaurs from the Upper Triassic of Nevada. Paläontographica, Abteilung A 170:139-200

Dal Sasso C, Pinna G (1996) Besanosaurus leptorhynchus n. gen. n. sp., a new Shastasaurid ichthyosaur from the Middle Triassic of Besano (Lombardy, N. Italy). Paleontologia Lombarda nuova serie 4:. 23

Gand G, Bourillot R, Brigaud B, Steyer J-S, Peyrouse J-B (2012) Les Reptiles et Synapsides fossiles de Bourgogne. Revue Scientifique Bourgogne-Nature, Hors-Série 12 (23-86)

Huene Fv (1902) Übersicht über die Reptilien der Trias. Geologische und Paläontologische Abhandlungen (Neue Serie) 6:1-84

Maisch MW, Matzke AT (1998) Observations on Triassic ichthyosaurs; Part III, A crested predatory mixosaurid from the Middle Triassic of the German Basin. Neues Jahrbuch für Geologie und Paläontologie Abhandlungen 209:105-134

Maisch MW, Pan X-R, Sun Z-Y, Cai T, Zhang D-P, Xie J-L (2006) Cranial osteology of Guizhouichthyosaurus tangae (Reptilia: Ichthysauria) from the Upper Triassic of China. J Vertebr Paleontol 26 (3):588-597

McGowan C (1994) A new species of Shastasaurus (Reptilia: Ichthyosauria) from the Triassic of British Columbia; the most complete exemplar of the genus. J Vertebr Paleontol 14:168-179

McGowan C (1997) A Transitional Ichthyosaur Fauna. In: Callaway JM, Nicholls EL (eds) Ancient Marine Reptiles. Academic Press, San Diego, California, pp 61-80

McGowan C, Motani R (1999) A Reinterpretation of the Upper Triassic ichthyosaur Shonisaurus. J Vertebr Paleontol 19 (1):42-49

McGowan C, Motani R (2003) Part 8. Ichthyopterygia, vol 8. Handbook of Paleoherpetology. Verlag Dr. Friedrich Pfeil, München

Motani R (1997) Temporal and Spatial Distribution of Tooth Implantation in Ichthyosaurs. In: Callaway JM, Nicholls EL (eds) Ancient Marine Reptiles. Academic Press, San Diego, California, pp 81-103

Motani R (1999) Phylogeny of the Ichthyopterygia. J Vertebr Paleontol 19 (3):473-496

Motani R, Manabe M, Dong Z-M (1999) The status of Himalayasaurus tibetensis (Ichthyopterygia). Paludicola 2:174-181

Nicholls EL, Manabe M (2001) A new genus of ichthyosaur from the Late Triassic Pardonet Formation of British Columbia : bridging the Triassic-Jurassic gap. Can J Earth Sci 38:9831002

Nicholls EL, Manabe M (2004) Giant ichthyosaurs of the Triassic-A new species of Shonisaurus from the Pardonet Formation (Norian: Late Triassic) of British Columbia. J Vertebr Paleontol 24 (4):838-849

Sander PM, Chen X, Cheng L, Wang X (2011) Short-snouted toothless ichthyosaur from China suggests Late Triassic diversification of suction feeding ichthyosaurs. PLoS ONE 6 (5):e19480

Sauvage HE (1876) Note sur les débris d'ichthyosaure des couches rhétiennes de Saône-et-Loire. Annales des Sciences Géologiques 7 (Article 6):1-1

Sauvage HE (1883) Recherches sur les reptiles trouvés dans l'étage rhétien des environs d'Autun. Annales des Sciences Géologiques 14 (6, article n³):1-44

Sauvage HE (1903) Note sur les reptiles de l'étage Rhétien des environs d'Autun. Bulletin de la Société d'Histoire naturelle d'Autun 16:309-318 
